\title{
Integrated tsunami vulnerability and risk assessment: application to the coastal area of El Salvador
}

\author{
P. González-Riancho ${ }^{1}$, I. Aguirre-Ayerbe ${ }^{1}$, O. García-Aguilar ${ }^{1}$, R. Medina ${ }^{1}$, M. González ${ }^{1}$, I. Aniel-Quiroga ${ }^{1}$, \\ O. Q. Gutiérrez ${ }^{1}$, J. A. Álvarez-Gómez ${ }^{2}$, J. Larreynaga ${ }^{3}$, and F. Gavidia ${ }^{3}$ \\ ${ }^{1}$ Environmental Hydraulics Institute IH Cantabria, Universidad de Cantabria, C/Isabel Torres no. 15, Parque Científico y \\ Tecnológico de Cantabria, 39011 Santander, Spain \\ ${ }^{2}$ Department of Geodynamics, Faculty of Geology, Complutense University of Madrid, C/ José Antonio Novais, s/n, 28040 \\ Madrid, Spain \\ ${ }^{3}$ Ministry of Environment and Natural Resources, Kilómetro 5 1/2 Carretera a Santa Tecla, Calle Las Mercedes, San \\ Salvador, El Salvador
}

Correspondence to: P. González-Riancho (grianchop@unican.es)

Received: 8 May 2013 - Published in Nat. Hazards Earth Syst. Sci. Discuss.: 26 June 2013

Revised: 28 March 2014 - Accepted: 4 April 2014 - Published: 22 May 2014

\begin{abstract}
Advances in the understanding and prediction of tsunami impacts allow for the development of risk reduction strategies for tsunami-prone areas. This paper presents a tsunami vulnerability and risk assessment for the case study of El Salvador, the applied methodology dealing with the complexity and variability of coastal zones by means of (i) an integral approach to cover the entire risk-related process from the hazard, vulnerability and risk assessments to the final risk management; (ii) an integrated approach to combine and aggregate the information stemming from the different dimensions of coupled human and natural systems; and (iii) a dynamic and scale-dependent approach to integrate the spatiotemporal variability considerations. This work also aims at establishing a clear connection to translate the vulnerability and risk assessment results into adequate target-oriented risk reduction measures, trying to bridge the gap between science and management for the tsunami hazard. The approach is applicable to other types of hazards, having been successfully applied to climate-change-related flooding hazard.
\end{abstract}

\section{Introduction}

Advances in the understanding and prediction of tsunami impacts allow for the development of risk reduction strategies for tsunami-prone areas. Tsunami risk assessments are essential for the identification of the exposed areas and of the most vulnerable communities and elements, with the hazard, vulnerability and risk results being critical for the formulation of adequate, site-specific and vulnerability-oriented risk management options.

Risk-related works in the literature differ according to the risk component analysed (i.e. hazard, exposure, vulnerability, impacts, resilience, coping capacity, etc.), the risk dimension dealt with (i.e. human, infrastructural, environmental, social, economic, etc.), and the spatial scale tackled (i.e. regional, national, local, etc.), thereby proving the complexity associated to risk assessment and management. Regarding the existing literature on tsunami risk, several authors centre their work on the tsunami hazard itself, trying to understand its evolution from the generation and propagation phases until its arrival at the coastal area with the aim of predicting the tsunami location, magnitude, duration and probability (Gosenberg and Schlurmann, 2009; Harbitz et al., 2012; Álvarez-Gómez, 2013), while others propose a methodology for the integration of various hazards (Greiving et al., 2006). On the other hand, some authors' analyses are oriented towards the calculation of vulnerability and/or impacts at a specific location (UNDP, 2011; UNU-EHS, 2009; Villagrán de León, 2008) or on specific elements at that location such as the population (Sugimoto et al., 2003; Sato et al., 2003; Koshimura et al., 2006; Jonkman et al., 2008; Strunz et al., 2011), the exposed buildings and infrastructures (Tinti et al., 2011; Dall'Osso et al., 2009; Cruz et al., 2009; Grezio et 
al., 2012; Koeri et al., 2009; Jelínek et al., 2009), the environmental resources (Fundación-Terram, 2012; ECLAC, 2003) or the socioeconomic system (ECLAC, 2003). Many deal with resilience, coping capacities, preparedness, etc. (UNESCO, 2009a; Wegscheider et al., 2011; US IOTWSP, 2007), with some of them concentrating on tsunami evacuation modelling (Van Zuilekom et al., 2005; Aboelata and Bowles, 2005; Mück, 2008; Clerveaux et al., 2008; Alvear Brito et al., 2009; Kolen et al., 2010).

Individual risk, hazard and/or vulnerability assessments can be partial, sectoral or specific. However, risk management requires an integrated and holistic understanding of the coupled human and natural system (CHANS) dealt with, otherwise management options can produce unexpected and sometimes undesired results. According to Rotmans and Dowlatabadi (1998), the integrated assessment is aimed at combining, interpreting and communicating knowledge from diverse scientific fields in order to comprehensively tackle an environmental problem by stressing its cause-effect links in their entirety. Integration refers in this paper to the understanding and combination of risk components, dimensions and scales affecting a CHANS, one of the major challenges being the systematic combination and aggregation of different types of data and information (i.e. quantitative vs. qualitative) from various disciplines, scales and data acquisition methodologies.

Vulnerability is multi-dimensional and differential, as it varies across physical space and among and within social groups; scale dependent regarding time, space and analysis units; and dynamic, as the characteristics and driving forces of vulnerability change over time (Vogel and O'Brien, 2004). The current literature encompasses several different definitions, concepts, frameworks and methods to systematise vulnerability (Birkmann, 2006), very little information being provided about how to apply the different existing theoretical and conceptual frameworks and how to integrate the different risk-related concepts. Furthermore, risk assessment results sometimes do not provide conclusions on how to reduce the risk at the identified areas, lacking a clear correlation between risk assessment and management.

The starting point of this work is the existing theoretical frameworks and approaches such as the MOVE framework (Birkmann et al., 2013), Turner et al. (2003) or the BBC conceptual framework (Birkmann, 2006). The main expected contribution is to provide a straightforward method to facilitate the implementation of some theoretical concepts to case studies, as this is sometimes complex due to site-specific problems, lack of data or the lack of information about particular methodological aspects. The final aim of the risk assessment is the identification of the expected impacts on each dimension as input for the formulation of adequate targetoriented risk reduction measures.

The objectives and structure of this paper are the presentation of the integrated tsunami vulnerability and risk assessment carried out in El Salvador, considering the different risk components, dimensions and spatiotemporal scales and the methodological process to integrate them (Sect. 2), and the establishment of a clear connection to translate the vulnerability and risk assessments into risk reduction measures, trying to bridge the gap between science and management for the tsunami hazard, and its application to the coastal area of El Salvador (Sect. 3). Finally, some conclusions are presented in Sect. 4.

\section{Integrated tsunami risk assessment for El Salvador}

Due to the large array of terms on risk and vulnerability and the often unclear relationships between them, it is essential to first clarify the conceptual framework applied in this paper. Regarding the risk components, this methodology is based on the definition of risk as the probability of expected harmful consequences or losses resulting from interactions between natural or human-induced hazards and vulnerable conditions (UN/ISDR, 2004), the mentioned consequences being the negative effects of disaster expressed in terms of human, economic, environmental, infrastructural and social impacts (adapted from ISO, 2009). Therefore, risk depends on the specific impact analysed (e.g. loss of human lives), the characteristics of the threat (e.g. flooding), the exposure of the studied elements (e.g. people in urban areas) and their vulnerability (sensitive groups and resilience).

The hazard as a dangerous phenomenon (UN/ISDR, 2009) is analysed based on the different associated threats (which are characterised by their location, intensity, duration, frequency and probability) together with their dynamics - i.e. variables and physical processes, involved in their generation. As an example, the specific threats to deal with when analysing climate change hazard could be, among others, sea level rise or an increase in tropical cyclones and droughts, while the dynamics to study would be waves, tides, sea level, sea temperature, precipitation, etc.

Exposure refers to people, property, systems, or other elements present in hazard zones that are thereby subject to potential losses (UN/ISDR, 2009), while vulnerability to the conditions is determined by physical, social, economic and environmental factors or processes, which increase the susceptibility of the exposed elements to the impact of hazards (adapted from UN/ISDR, 2004). These vulnerability conditions are here understood to be of two types, internal (unchangeable individual conditions, such as the age of the population) and external (changeable community conditions, improvable through learning and experience, such as risk preparedness within the communities), the improvement of the latter being a possible countermeasure to reduce the vulnerability of highly sensitive areas. Accordingly, sensitivity refers to the intrinsic characteristics of the exposed elements that make them potentially affected by physical or socioeconomic changes, including damage and losses (adapted from UN/ISDR, 2004), while resilience is the ability of a 
system, community or society exposed to hazards to resist, absorb, accommodate to and recover from the effects of a hazard in a timely and efficient manner, including through the preservation and restoration of its essential basic structures and functions (UN/ISDR, 2009).

The success or failure of many policies and management practices is based on their ability to take into account complexities of CHANS (Liu et al., 2007). Understanding the interrelationships between human societies and their behaviour patterns, coastal resources and their uses, as well as policies and institutions that govern human activities is essential for adequate coastal management. This requires an integrated and multidisciplinary approach to analyse the entire system in order to understand the feedback loops that manage its behaviour and equilibrium instead of simply considering specific aspects of a single sector or scientific discipline. This approach is applied here throughout the exposure and vulnerability assessments, as they are fragmented to incorporate different coastal dimensions (human, environmental, socioeconomic and infrastructural dimensions) within the tsunami risk assessment, based on EC (2010), the Hyogo Framework for Action (UN, 2005) and the impacts generated in recent tsunami events. Contrary to other previous works found in the literature, the human and socioeconomic dimensions are separated here on purpose, as the information regarding the human dimension will directly feed the evacuation planning of the area (González-Riancho et al., 2013), while the socioeconomic dimension focuses on livelihoods and economic losses. The elements at risk vary with time and space, as both factors will change the amount and type of exposed and vulnerable elements. For this reason, and according to EC (2010), impact assessments are defined based on a reference space-time window.

Figure 1 shows the entire process to integrate the risk components, dimensions and spatial scales. Regarding the integration of dimensions and according to EC (2010), two types of results are provided, partial and aggregated results. The former allow having the analysed impacts available separately for the different dimensions and components, while the latter combines all the dimensions. Based on the results of the risk assessment and according to UNESCO (2009b), the risk can be mitigated by reducing the vulnerability to the hazard and improving preparedness. Within the work presented here, this translates into the formulation of risk reduction measures to reduce the partial exposure and sensitivity, and to enhance the resilience at the municipality level.

As shown through the colour-coded arrows, the construction of aggregated indices - i.e. exposure, sensitivity and vulnerability, is performed through weighted aggregation (blue vertical arrows) while the risk calculation, both partial and aggregated results, is performed through the risk matrix (red horizontal arrows). The main advantage of this approach is the generation of partial and aggregated results as well as the possibility of disaggregating them again into risk components, dimensions and indicators, in order to understand the precise cause of the obtained results, and thereby provide essential information for risk management (black arrows).

This approach, although presented in this paper for the tsunami hazard, can be used for other types of hazards, having been already applied by IH Cantabria to climate changerelated flooding in Peru and El Salvador within the framework of the Inter-American Development Bank project Probabilistic Hazard and Vulnerability Assessment Report based on Climate Change Projections (2012).

\subsection{Case study}

El Salvador is located in an area of high seismic activity which was hit by 15 tsunamis between 1859 and 2012, 9 of which were recorded in the 20th century. All of the tsunamis were generated by earthquakes, and two of them were highly destructive; one in 1902 that affected the eastern coast of the country and one in 1957 that affected Acajutla. The most recent, albeit of lesser magnitude, occurred in August 2012, affecting Jiquilisco Bay (IH Cantabria-MARN, 2012). The work presented here is framed within a project for assessing the tsunami risk in coastal areas worldwide, and applied specifically to the coast of El Salvador during the 2009-2012 period.

Table 1 shows the specific structure of the tsunami risk assessment applied to the coastal area of El Salvador, which is based on the pre-established expected consequences that are of interest to the Ministry of Environment and Natural Resources (MARN) of El Salvador; it is according to them that the vulnerability indicators (described in Sect. 2.3) are defined.

The spatial scale considers the national and local levels, the municipality being the planning unit. The national level includes the 29 coastal municipalities, while the local scale focuses on 3 specific areas that include 10 municipalities: the Western Coastal Plain (San Francisco Menéndez, Jujutla and Acajutla municipalities), La Libertad municipality and Jiquilisco Bay (Jiquilisco, Puerto El Triunfo, Usulután, San Dionisio, Jucuarán and Concepción Batres municipalities). As proposed by Turner et al. (2003), different factors shaping the risk at various spatio-temporal scales are considered, the population movements due to holiday patterns (rainy season/dry season, week/weekend) in the human system and the migration patterns or breeding/nesting periods for the environmental system.

The hazard assessment is carried out through a deterministic analysis to understand the worst possible case scenario, as carried out by Jelínek et al. (2009) and Wijetunge (2014). The use of a deterministic approach does not allow for the provision of the risk results in terms of a probability of negative consequences for different tsunami return periods; instead it permits the identification, location and quantification of the expected negative consequences or impacts for the worst possible credible scenario as the main outcome of the risk assessment. To calculate the expected consequences, the 


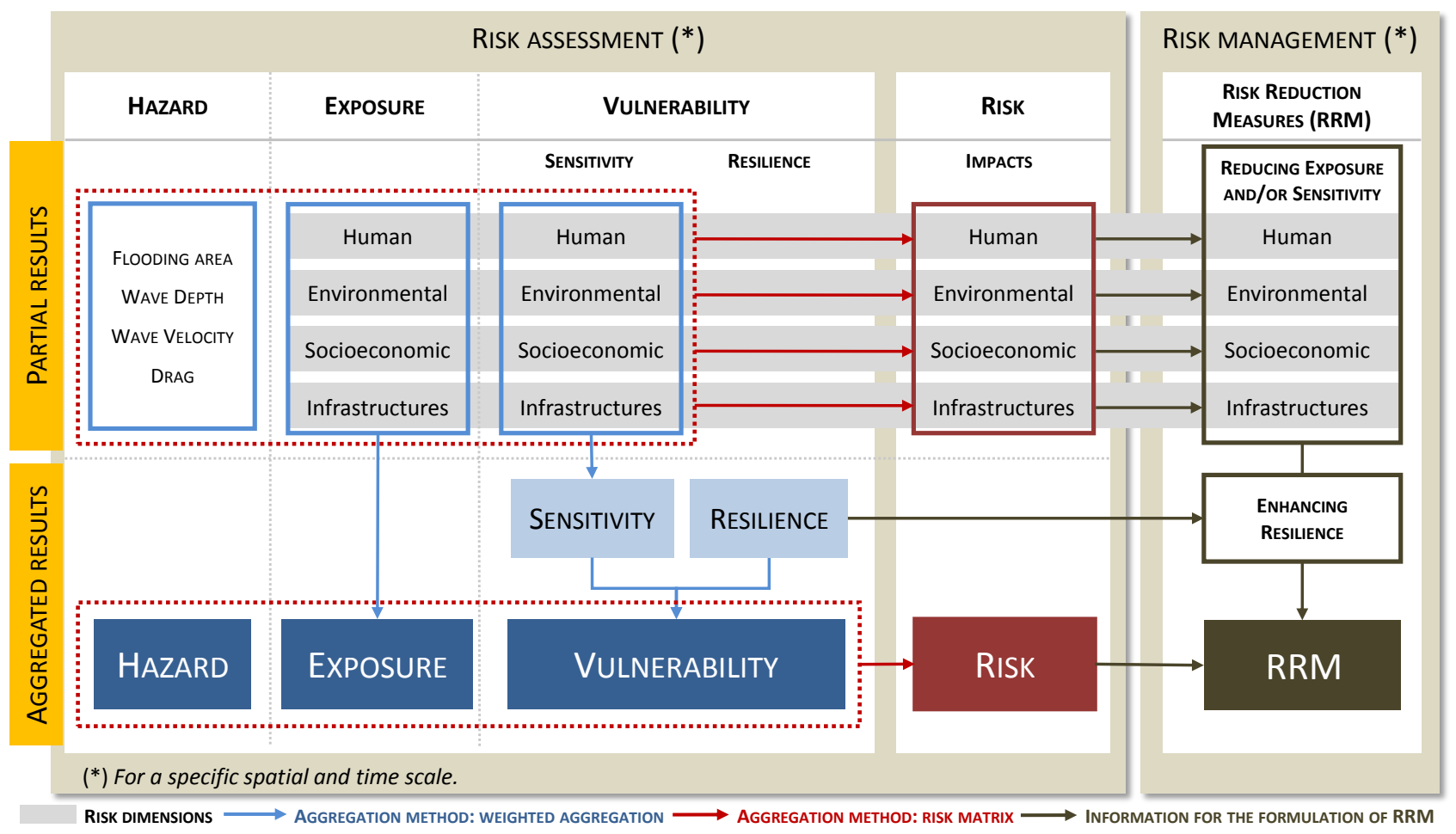

Figure 1. Structure of the risk assessment and different kind of results to be obtained (RRM = risk reduction measures).

threat analysis differs according to each dimension to better understand the potential impacts or due to the lack of detailed information and/or methods in the literature to assess the specific damage levels. As a result, in this case study drag is applied to the human dimension, water depth to buildings, and flooded area to the environmental, socioeconomic and infrastructural dimensions.

Accordingly, the national assessment focuses on the identification of the most critical municipalities in terms of likelihood of impacts for the worst credible event, which facilitates their prioritisation regarding further detailed studies, risk management efforts and resources (Fletcher, 2005). The likelihood of impacts within this qualitative risk assessment derives from the vulnerability variability and uncertainties. The local assessment aims at the calculation of specific expected impacts on the different dimensions by municipality. These worst-credible-event results allow the authorities organising and managing the risk to provide the most protective situation, so that the formulation of measures is on the side of safety and as conservative as possible in order to ensure their validity for different scenarios. Some of the results obtained for the national level and the Western Coastal Plain are presented in this paper.

\subsection{Tsunami hazard assessment}

The hazard assessment is based on propagation models for earthquake-generated tsunamis, developed through the char- acterisation of tsunamigenic sources - seismotectonic faults - and other dynamics such as tsunami waves, sea level, etc. Simulations of historical and potential tsunamis with greater or lesser impacts on the country's coast have been performed (Fig. 2), including distant sources (distances greater than $2000 \mathrm{~km}$ to the coast, with tsunami travel times greater than $4 \mathrm{~h}$ ), regional sources (between 700 and $2000 \mathrm{~km}$ with tsunami travel times between 1 and $4 \mathrm{~h}$ ), and local sources (located in the subduction trench off the country's coast with tsunami travel times of less than $1 \mathrm{~h}$ ).

The numerical propagations have been simulated using the C3 model "Cantabria-Comcot-Tsunami-Claw model" (Olabarrieta et al., 2011). This model was developed by IH Cantabria and it combines two models: COMCOT and Tsunami-Claw (LeVeque et al., 2011) in order to solve nonlinear shallow water equations (NSWE). C3 is a finite differences numerical model validated and applied to several historical tsunami events such as the 1960 Chilean tsunami (Liu et al., 1994), the 1992 Flores Islands (Indonesia) tsunami, the 2004 Indian Ocean tsunami and the Algerian tsunami 2003 (Wang and Liu, 2005). Additionally, the model has been validated using the benchmark cases proposed within the framework of the European Tsunami Project TRANSFER (Tsunami Risk And Strategy For the European Region). $\mathrm{C} 3$ is especially designed to simulate tsunami events. The parameters of the earthquake can be introduced via the Okada fault model (Okada, 1985). The model then solves the NSWE using a gridded domain. It provides data such as free surface 
Table 1. Structure of the Tsunami Risk Assessment applied to El Salvador coastal area.

\begin{tabular}{|c|c|c|c|c|c|c|c|c|}
\hline \multicolumn{2}{|l|}{ Risk } & \multirow[b]{2}{*}{$\begin{array}{l}\text { Spatial } \\
\text { scale }\end{array}$} & \multirow[b]{2}{*}{ Probability } & \multirow{2}{*}{$\begin{array}{l}\text { Hazard } \\
\text { Dynamics }\end{array}$} & \multirow[b]{2}{*}{ Threat } & \multirow{2}{*}{$\begin{array}{c}\text { Exposure } \\
\text { Exposed } \\
\text { elements }\end{array}$} & \multicolumn{2}{|c|}{ Vulnerability } \\
\hline Consequences & $\begin{array}{l}\text { Time- } \\
\text { scale }\end{array}$ & & & & & & Sensitivity & Resilience \\
\hline $\begin{array}{l}\text { Loss of lives due to } \\
\text { - } \quad \text { reduced mobility } \\
\text { difficulties understanding a } \\
\text { warning message } \\
\text { bad housing materials and lack of } \\
\text { recovery capacity } \\
\text { difficulties in receiving a warning } \\
\text { and evacuating in badly } \\
\text { connected areas } \\
\text { difficulties in performing a } \\
\text { coordinated evacuation }\end{array}$ & 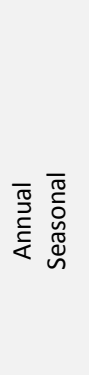 & $\begin{array}{l}\bar{\pi} \\
\stackrel{\overline{0}}{\bar{\pi}} \overline{\mathscr{J}} \\
\frac{\pi}{2}\end{array}$ & & & 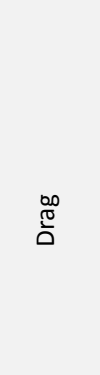 & $\begin{array}{l}\frac{0}{0} \\
\frac{0}{0} \\
0\end{array}$ & $\begin{array}{l}\text { Sensitive age groups } \\
\text { Illiteracy } \\
\text { Extreme poverty } \\
\text { Disability } \\
\text { (physical/intellectual) } \\
\text { Isolation } \\
\text { Critical evacuation }\end{array}$ & \\
\hline $\begin{array}{l}\text { Loss of protected ecosystems } \\
\text { Loss of unique ecosystems (coral reef) } \\
\text { Loss of ecosystem services (mangrove) } \\
\text { Loss of endangered species } \\
\text { Permanent destruction of ecosystems }\end{array}$ & 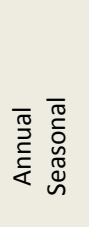 & 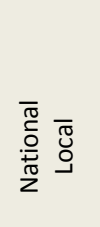 & 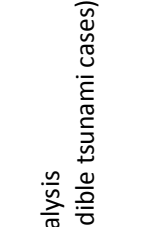 & $\stackrel{\varrho}{\circlearrowright}$ & 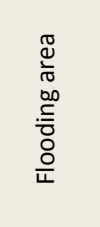 & 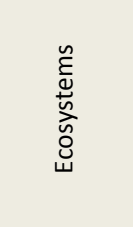 & $\begin{array}{l}\text { Protection } \\
\text { Singularity } \\
\text { Threat } \\
\text { Degradation }\end{array}$ & 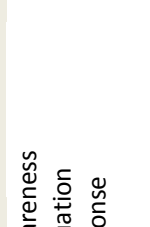 \\
\hline $\begin{array}{l}\text { Loss of area of socioeconomic activities } \\
\text { Loss of jobs } \\
\text { Loss of gross domestic product (GDP) } \\
\text { Loss of foreign trade }\end{array}$ & $\begin{array}{l}\bar{T} \\
\stackrel{T}{2} \\
\frac{1}{2} \\
\frac{1}{4}\end{array}$ & 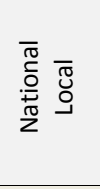 & 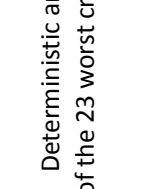 & 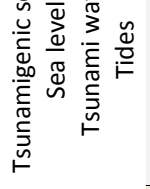 & $\begin{array}{l}\stackrel{\infty}{\subseteq} \\
\frac{\pi}{0} \\
\frac{0}{\frac{0}{4}}\end{array}$ & 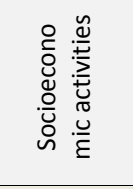 & $\begin{array}{l}\text { Job generation } \\
\text { Contribution to GDP } \\
\text { Contribution to foreign } \\
\text { trade }\end{array}$ & 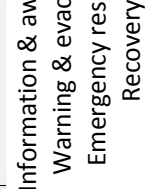 \\
\hline $\begin{array}{l}\text { Pollution of wells, hindering long-term } \\
\text { water supply to local communities } \\
\text { Loss of essential evacuation routes } \\
\text { Generation of cascading impacts due } \\
\text { to hazardous/dangerous industries } \\
\text { Loss of emergency and health services, } \\
\text { essential during the event }\end{array}$ & $\begin{array}{l}\bar{T} \\
\stackrel{0}{\frac{1}{2}} \\
\frac{1}{4}\end{array}$ & 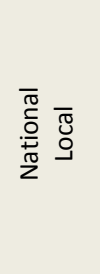 & 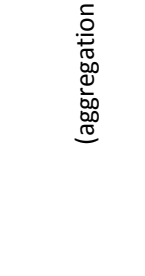 & & 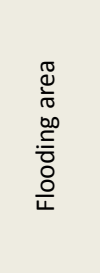 & 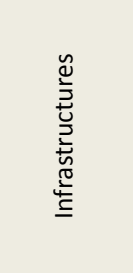 & $\begin{array}{l}\text { Water supply (wells) } \\
\text { Roads } \\
\text { Hazardous/dangerous } \\
\text { industries } \\
\text { Emergency/health } \\
\text { infrastructures }\end{array}$ & \\
\hline $\begin{array}{l}\text { Impacts on critical buildings (housing } \\
\text { large population) } \\
\text { Loss of potential vertical shelters } \\
\text { Destruction of buildings }\end{array}$ & $\begin{array}{l}\bar{T} \\
\stackrel{0}{2} \\
\frac{1}{2} \\
\frac{1}{4}\end{array}$ & 등 & & & 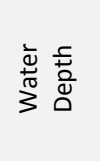 & 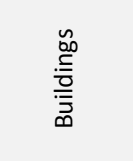 & $\begin{array}{l}\text { Critical buildings } \\
\text { Vertical evacuation } \\
\text { Building materials }\end{array}$ & \\
\hline
\end{tabular}

elevation at every point on the grid, or temporal series of velocity and total depth at each point. In the case studied in this paper, 4 levels of nested grids have been used in order to obtain a cell size of $30 \mathrm{~m}$ on the coast of El Salvador. The run-up calculation at the areas where no local grids were available has been carried out using the Synolakis (1987) validated empirical formulations. Further information on this hazard assessment is provided by Álvarez-Gómez et al. (2013) and IH Cantabria-MARN (2010).

As mentioned above, a deterministic analysis which aggregates the 23 worst credible cases of tsunamis that could impact on the Salvadoran coast (see Fig. 2) has been carried out, with the main output being different hazard maps along the coast of El Salvador and at some relevant locations with high-resolution analysis. The generated hazard maps include the following: maximum wave height elevation, maxi- mum water depth, minimum tsunami arrival time, maximum flooding level or "run-up", and maximum potential drag (understood as the hazard degree for human instability based on incipient water velocity and depth). Fig. 5a shows one of the tsunami hazard maps generated at the national level, which allows for the identification of the areas subjected to higher tsunami water depths and consequently to a higher impact.

\subsection{Tsunami vulnerability and risk assessment}

The hazard area calculated allows identifying the number and type of exposed elements for the four dimensions (i.e. human, environmental, socioeconomic and infrastructural). The exposure assessment identifies the elements located in the hazard area, while the vulnerability assessment measures the characteristics of the exposed elements that make them 

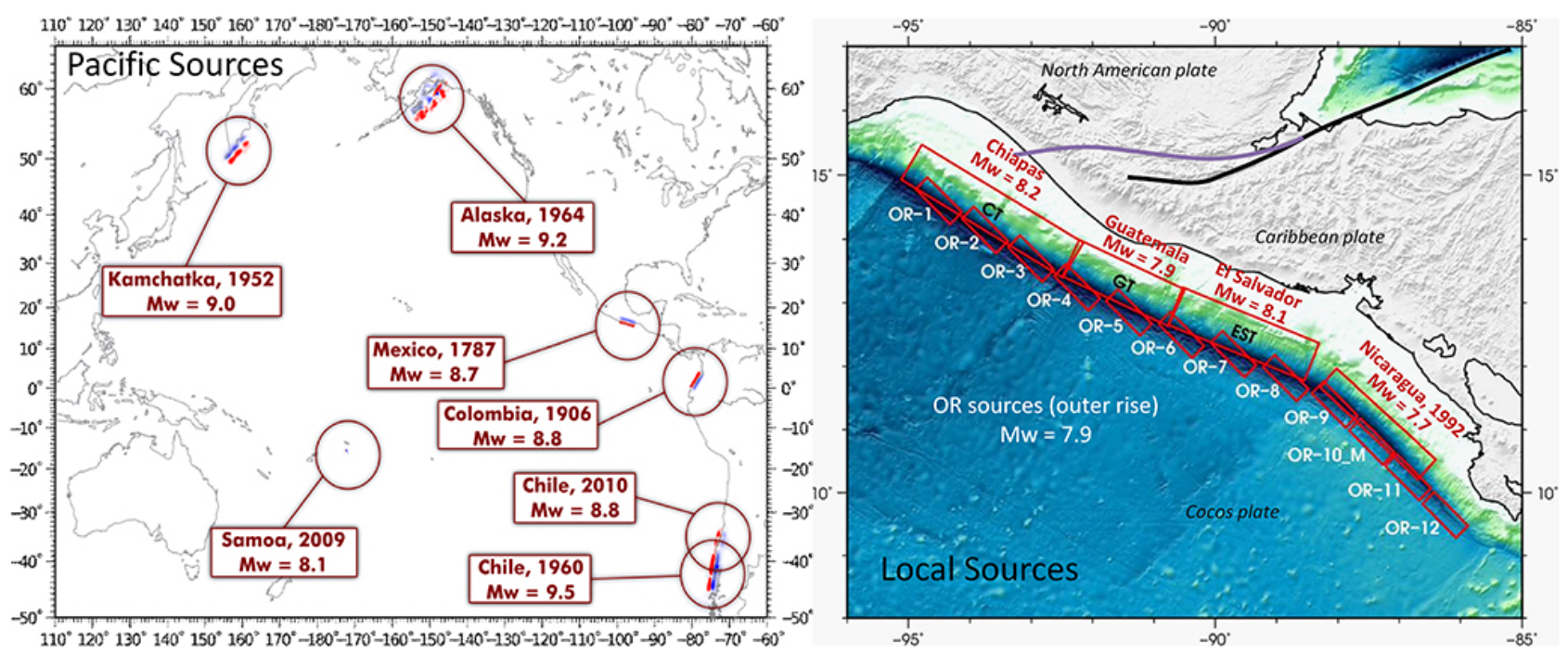

Figure 2. Distant, regional and local tsunamigenic sources of historical and potential tsunamis that could impact on the Salvadoran coast have been aggregated for the deterministic hazard assessment.

susceptible to suffering the selected impacts. Thus, vulnerability focuses on the expected impacts by municipality on the different dimensions and their potential worsening implications for the populations due to existing feedback loops (for example, the loss of household income due to loss of livelihood-related natural resources, the loss of recovery capacity of the country due to the loss of area of specific socioeconomic activities, or the lack of long-term water resources for some coastal communities due to the affection of coastal wells, among others). This is the main justification for the mixed indicator approach presented below. A partial human analysis could seem enough for reducing life losses; however, understanding all the potential implications of a tsunami event in a specific area will help in promoting awareness and preparedness. On the other hand, this global understanding of the system has the disadvantage of sometimes resulting in a superficial analysis of some of the impacts analysed.

Two different and complementary aspects for feedback loops existing in CHANS are perceived depending on the reference to specific static assessments or to holistic and timeevolving management. As described by Cutter et al. (2008) for the antecedent conditions of resilience, the sensitivity assessment is carried out in this work for a specific moment, it can be seen as a snapshot in time or a statistic state, the result being a precise value for each partial sensitivity (human, environmental, etc.) independently of the existing feedback loops within the system. Feedback loops are essential and are considered in this work as the only way to understand the behaviour of the system and to correctly manage it in terms of risk reduction, this being the reason for designing the set of indicators through the integrated approach.

\subsubsection{Definition of exposure and vulnerability indicators}

A set of indices and indicators are developed to calculate the exposure and sensitivity of the coastal dimensions as well as the resilience of the society and communities at risk. To carry this task out, several mathematical-statistical procedures are applied in order to produce comparable and combinable information. A Geographic Information System allows supporting every decision with geo-referenced information, being an essential tool for the combination of partial maps related to each dimension and particularly useful for evacuation modelling and planning (González-Riancho et al., 2013). The following sections describe the set of indicators and the methodology used to integrate them.

Based on the steps suggested by the Handbook on Constructing Composite Indicators (OECD, 2008), the proposed set of indicators is presented in Table 2. This set is adapted to different spatiotemporal scales: the spatial scale includes both national and local levels, while the timescale considers the movements caused by holiday patterns in the human population. It is important to point out the analytical soundness of all the indicators, the independence among them and the relevance of the measured phenomenon. The robustness, sensitivity and transparency of the indicator system allow managing the information at the index level as well as separating them into the different indicators and working directly with the base data, which is essential for not losing information while aggregating results, and for the formulation of adequate risk reduction measures.

The human sensitivity indicators (S1-S6) are oriented to measure the municipalities' weaknesses in terms of evacuation and recovery capacities of the exposed population. Accordingly, difficulties in understanding a warning message 
Table 2. Tsunami Exposure and Vulnerability indices and indicators $(\mathrm{N}=$ national scale, $\mathrm{L}=$ local scale, GDP $=$ gross domestic product $)$.

\begin{tabular}{|c|c|c|c|c|}
\hline $\begin{array}{l}\text { Aggregate } \\
\text { index }\end{array}$ & $\begin{array}{l}\text { Partial } \\
\text { indices }\end{array}$ & Indicators & Variables & $\begin{array}{l}\text { Spatial } \\
\text { scale }\end{array}$ \\
\hline \multirow{5}{*}{ 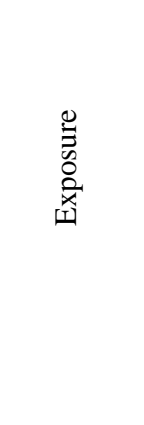 } & $\begin{array}{l}\text { Human } \\
\text { Exposure }\end{array}$ & E1 - Exposed population & $\begin{array}{l}\text { Number of persons permanently exposed } \\
\text { Number of persons temporally exposed (holidays) }\end{array}$ & $\begin{array}{l}\mathrm{N}-\mathrm{L} \\
\mathrm{N}-\mathrm{L}\end{array}$ \\
\hline & $\begin{array}{l}\text { Environmental } \\
\text { Exposure }\end{array}$ & E2 - Exposed ecosystems & Area of exposed ecosystems & $\mathrm{N}-\mathrm{L}$ \\
\hline & $\begin{array}{l}\text { Socioeconomic } \\
\text { Exposure }\end{array}$ & $\begin{array}{l}\text { E3 - Exposed socioeconomic } \\
\text { activities }\end{array}$ & $\begin{array}{l}\text { Area of exposed activities (agriculture and herding, } \\
\text { fishing, aquaculture, tourism, industry, trade, services) }\end{array}$ & $\mathrm{N}-\mathrm{L}$ \\
\hline & Infrastructures & E4 - Exposed infrastructures & $\begin{array}{l}\text { Number of exposed infrastructures (water, energy, } \\
\text { waste treatment, transport, industrial, emergency) }\end{array}$ & $\mathrm{N}-\mathrm{L}$ \\
\hline & Exposure & E5 - Exposed buildings & Number of exposed buildings & $\mathrm{L}$ \\
\hline \multirow{17}{*}{ 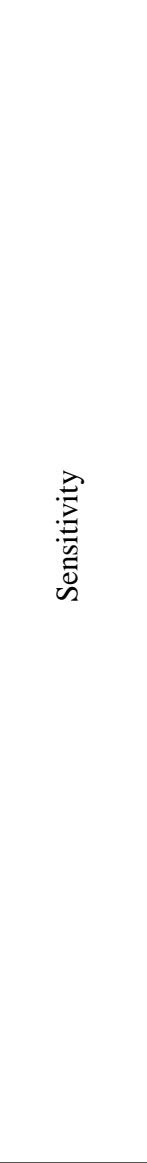 } & \multirow{6}{*}{$\begin{array}{l}\text { Human } \\
\text { Sensitivity }\end{array}$} & S1 - Sensitive age groups & $\begin{array}{l}\text { Number of persons under } 10 \text { years } \\
\text { Number of persons over } 65 \text { years }\end{array}$ & $\begin{array}{l}\mathrm{N}-\mathrm{L} \\
\mathrm{N}-\mathrm{L}\end{array}$ \\
\hline & & S2 - Illiteracy & Number of illiterate persons & $\mathrm{N}-\mathrm{L}$ \\
\hline & & S3 - Extreme poverty & Number of persons in extreme poverty conditions & $\mathrm{N}-\mathrm{L}$ \\
\hline & & S4 - Disability & Number of disabled persons (physical/intellectual) & $\mathrm{L}$ \\
\hline & & S5 - Isolation & Number of persons in isolated areas & $\mathrm{L}$ \\
\hline & & S6 - Critical evacuation & Number of persons in critical buildings & $\mathrm{L}$ \\
\hline & \multirow{4}{*}{$\begin{array}{l}\text { Environmental } \\
\text { Sensitivity }\end{array}$} & S7 - Protection & Area of protected ecosystems & $\mathrm{N}-\mathrm{L}$ \\
\hline & & S8 - Singularity & Area of singular ecosystems (ecosystem services) & $\mathrm{N}-\mathrm{L}$ \\
\hline & & S9 - Threat & Area of threatened ecosystems & $\mathrm{N}-\mathrm{L}$ \\
\hline & & S10 - Degradation & Area of degraded ecosystems & $\mathrm{L}$ \\
\hline & \multirow{3}{*}{$\begin{array}{l}\text { Socioeconomic } \\
\text { Sensitivity }\end{array}$} & S11 - Job generation & Number of workers per activity & $\mathrm{N}-\mathrm{L}$ \\
\hline & & S12 - Contribution to GDP & Millions of dollars contributed per activity & $\mathrm{N}-\mathrm{L}$ \\
\hline & & S13 - Contribution to foreign trade & Millions of dollars contributed per activity & $\mathrm{N}-\mathrm{L}$ \\
\hline & \multirow{4}{*}{$\begin{array}{l}\text { Infrastructures } \\
\text { Sensitivity }\end{array}$} & S14 - Critical infrastructures & $\begin{array}{l}\text { Number of water supply infrastructures (wells) } \\
\text { Number of transport infrastructures (evacuation) } \\
\text { Number of dangerous/hazardous infrastructures } \\
\text { Number of emergency infrastructures }\end{array}$ & $\begin{array}{l}\mathrm{N}-\mathrm{L} \\
\mathrm{N}-\mathrm{L} \\
\mathrm{N}-\mathrm{L} \\
\mathrm{N}-\mathrm{L}\end{array}$ \\
\hline & & S15 - Critical buildings & $\begin{array}{l}\text { Number of critical buildings (hospitals, schools, } \\
\text { hotels, malls, stadiums, churches, etc.) }\end{array}$ & $\mathrm{L}$ \\
\hline & & S16 - Vertical evacuation & Number of buildings with less than three stories & $\mathrm{L}$ \\
\hline & & S17 - Building materials & Number of non-resistant buildings & $\mathrm{L}$ \\
\hline \multirow{2}{*}{ 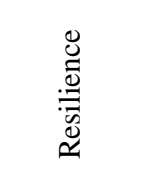 } & \multirow[t]{2}{*}{ Resilience } & R1 - Coping capacity & $\begin{array}{l}\text { Information and awareness level } \\
\text { Warning and evacuation level } \\
\text { Emergency response level }\end{array}$ & $\begin{array}{l}\mathrm{N}-\mathrm{L} \\
\mathrm{N}-\mathrm{L} \\
\mathrm{N}-\mathrm{L}\end{array}$ \\
\hline & & R2 - Recovery capacity & Post-disaster recovery level & $\mathrm{N}-\mathrm{L}$ \\
\hline
\end{tabular}

(S1, S2, S4-intellectual disability), problems with mobility and reduced evacuation speed (S1, S4-physical disability), difficulties with evacuation related to the built environment and coordinated evacuations (S6), difficulties with receiving a warning message and reaching the safe area before the tsunami arrives (S5); and the difficulties in recovering after a disaster (S3) are analysed.

The environmental sensitivity indicators (S7-S10) aim to assess the potential environmental impacts by municipality in terms of loss of ecosystems and the subsequent loss of 
livelihood-related ecosystem services. Thus, the loss of relevant ecosystems (S7, S8, S9), the potential permanent destruction of ecosystems (S10), and the loss of livelihoodrelated ecosystem services, such as coral reefs and mangroves (S8) is assessed. The potential capacity of mangroves to mitigate the hazard is included in this work through the hazard assessment, as a higher roughness coefficient was assigned to mangrove areas.

The socioeconomic sensitivity indicators (S11-S13) are oriented to measure the potential social and economic impacts by municipality in terms of loss of income at the household level and economic losses for the country, respectively. The social impacts (S11) are calculated through the number of jobs that would be lost per socioeconomic activity, while the economic impacts (S12, S13) are expressed in millions of dollars lost per socioeconomic activity in case of having a percentage of its area affected.

The infrastructures sensitivity indicators (S14-S17) measure the number of critical infrastructures and buildings that would be affected by municipality and the subsequent implications for the population, the term critical applied to those elements that if affected would worsen the situation both during and after the event. Accordingly, S14 calculates the potential number of polluted wells hindering long-term water supply to local communities, loss of essential evacuation routes, generation of cascading impacts due to affected hazardous/dangerous industries, and loss of emergency and health services which are essential during the event. S15 provides the number of buildings that would require a coordinated and previously planned evacuation due to the high number of people (in some cases sensitive population) in them, such as hospitals, schools, clinics for elderly people, malls, stadiums, churches, hotels, etc. S16 and S17 measure the number of buildings not able to provide shelter for the population, due to the number of floors or to the weak materials. S17 permits the calculation of the buildings damage level according to the materials and the water depth (based on SCHEMA methodology by Tinti et al., 2011). The damage level of the specific infrastructures (water, energy, industrial, transport, emergency) is not included in this study.

The Pearson correlation coefficient was calculated to select the indicators. Most of the indicators had low correlation except extreme poverty \& illiteracy $(r=0.92)$, environmental threat \& protection $(r=0.68)$, and GDP contribution \& job generation $(r=0.90)$. These relationships between variables were carefully evaluated to consider the removal of some of them; however, their analytical relevance and differentiation prevailed to the correlation result, as agreed by the assistants in a participatory workshop and for the sake of better refined risk reduction measures. In this sense, (i) poverty gives information about areas which would struggle more after the event due to the lack of financial resources to recover, while illiteracy provides information about the ability to understand a warning message during the event; (ii) maintaining both threat and protection indicators permitted the identi- fication of areas where unprotected endangered species were located and formulate specific measures for these areas; (iii) maintaining both GDP contribution and job generation permitted a clear differentiation between social and economic impacts of the event to understand the medium to long-term effects of the tsunami. Weights have been carefully assigned to these indicators to correct the doubling effects when aggregating.

Data collection for exposure and sensitivity indicators is based on the best available information for the human ${ }^{1}$, environmental $^{2}$, socioeconomic ${ }^{3}$ and infrastructural ${ }^{4}$ dimensions in El Salvador. Besides this, field work was carried out to produce the information that was not officially available or that was incomplete, such as the one regarding isolated communities (with the help of local authorities and Civil Protection local departments), critical buildings, building materials and vertical evacuation.

The consideration of factors shaping risk at various scales (as proposed by Turner et al., 2003) is considered in this paper through the variable "Number of persons exposed temporarily (holidays)" within the human exposure indicator, which permitted the comparison of specific areas at different times of the year (spatio-temporal variability) and showing higher exposure and vulnerability values in holiday periods. This effect in specific hotspots is explained by holiday movements of foreigners to very specific sites and associated for example with surf promotion campaigns developed at the national level. These overcrowded places are likely to be higher risk areas in holiday periods. Other factors that could be considered are the planned coastal development for the coming years in exposed areas, or national initiatives (like the one resulting in this paper) which are aimed at reducing the vulnerability of communities at the local level. Further research work is needed in order to properly include these types of factors within risk assessments.

An additional explanation is provided for the resilience assessment. The resilience of a community with respect to potential hazard events is determined by the degree to which the community has the necessary resources and is capable of absorbing disturbance and reorganising into a fully functioning system (Cutter et al., 2008). This is understood as the capacity of a community to organise itself before, during and after the event in order to minimise the impacts. Thus, two of society's capacities are analysed to evaluate the

\footnotetext{
${ }^{1}$ Censo de Población 2007, Encuesta de Hogares de Propósitos Múltiples 2011 (Dirección General de Estadística y Censos DIGESTYC), Ministerio de Turismo MITUR

${ }^{2}$ Ministerio de Medio Ambiente y Recursos Naturales MARN

${ }^{3}$ DIGESTYC 2007, Banco Central de Reserva BCR

${ }^{4}$ Asociación Nacional de Acueductos y Alcantarillados ANDA, Comisión Hidroeléctrica del Rio Lempa CEL, Comisión Ejecutiva Portuaria Autónoma CEPA, Ministerio de Obras Públicas MOP, Ministerio de Economía MINEC, Centro de Desarrollo de la Pesca y la Acuicultura CENDEPESCA, Ministerio de Agricultura y Ganadería, Fuerza Naval, and Ministerio de Turismo MITUR
} 
resilience: coping capacity, as the ability of people, organisations and systems, using available skills and resources, to face and manage adverse conditions, emergencies or disasters (UN/ISDR, 2009) before and during the event; and recovery capacity, as the ability of the system to recover after a disaster. These two indicators are assessed through the analysis of the four phases of emergency management: information and awareness, warning and evacuation, emergency response, and disaster recovery.

Due to the lack of thematic and geographically homogeneous data regarding resilience, data collection for the construction of the resilience index has been carried out through a short questionnaire which identifies the degree of organisation and response within a community in case of an emergency. The type of questionnaire applied is based on the assessment of the level of implementation of Integrated Coastal Zone Management (ICZM) in Europe, proposed by Pickaver et al. (2004) and carried out through a questionnaire with three possible answers (yes/no/no answer) against each ICZM action and for three spatial levels to identify the main existing gaps in ICZM implementation and a trend through time. Using appropriate questionnaires for the resilience assessment solves the commonly faced problem regarding the limits of measurability and the collection of quantitative data to be analysed together with the sensitivity data. Table 3 shows the relation between the elements of resilience, the phases of emergency management and the questionnaire.

The resilience questionnaire offers three response alternatives, yes/no/partially, together with space for fuller comments, and has been filled in by 34 stakeholders. Although the statistical sample could be considered small, the coherence of the assessment is ensured at the national level through the answers of those responsible for emergency management in every coastal municipality (Municipal Civil Protection Committees). Additional stakeholders were interviewed for the local studies, such as some nongovernmental organisations, companies and business associations, and community leaders; in case of contradictory answers ("yes/no") the intermediate value ("partially") has been finally assigned, the incoherence between authorities' and society's perception about the preparedness of the municipality being automatically identified as a critical issue for resilience enhancement measures.

The complexity of having the resilience as a component inversely proportional to risk (a higher resilience reduces the risk) in a multidisciplinary study, which combines different risk components, dimensions and timescales and therefore indicators from various disciplines, sources and units, highlights the need to translate this factor into a directly proportional one. Therefore, the authors propose the use of a new component named "lack of resilience", as applied by the MOVE framework (Birkmann et al., 2013). Consequently, the indicators coping capacity and recovery capacity will analyse the lack of resilience and focus on the negative responses of the questionnaire. The aggregation of each type of answer multiplied by its coefficient and divided by the total number of questions providing the value of the lack of resilience index, the coefficients being 0,1 and 0.5 for positive, negative and intermediate answers, respectively. This is necessary for aggregation purposes (i.e. aggregating sensitivity and resilience to build the vulnerability); however, to analyse the resilience itself, the lack of resilience is translated again into the resilience concept through the expression Resilience $=1-$ Lack of resilience

\subsubsection{Integration of risk concepts}

The method for the integration of risk concepts included in the process from the exposure and vulnerability data collection and processing up to the risk assessment is explained in the next paragraphs. This method has several steps: (i) building indicators through normalizations; (ii) building partial and aggregated indices through weighted aggregation, (iii) index classification via the natural breaks method; and (iv) risk assessment using the risk matrix.

Based on OECD (2008), in order to correct the imbalance caused by the different variable units, thus allowing for their comparison and combination, the transformation of the variables range of values is carried out through the minimummaximum (Min-Max) method, which normalises the indicators so as to obtain an identical range [0,1]. A weighted aggregation is applied to them in order to build the partial (for each dimension) and aggregated indices. Weights are assigned in this work using participatory methods: a workshop has allowed the authors to collect the opinions of different experts, with the participation of 10 technicians from the MARN (Ministry of Environment and Natural Resources, El Salvador) and the team from IH Cantabria (Environmental Hydraulics Institute, Spain), in order to reflect political and social priorities, technical factors related to the tsunami hazard and the reliability of the data used.

As carried out by Damm (2010) and the World Risk Report (Alliance Development Works, 2012), among others, the indices are classified considering the data distribution and translated into five classes linked to a colour code geographically representing the information. The natural breaks classification method, based on the Jenk's optimisation algorithm, implemented in ArcGIS ${ }^{\circledR}$ software and designed to provide the best arrangement of values into different classes, is applied. The method reduces the variance within classes and maximises the variance between classes (Jenks, 1967) and has been selected after testing other methods (such as the equal interval, defined interval, quantile, geometrical interval, standard deviation, etc.), as it permits grouping within the same class the municipalities that have similar values, that is those that behave in the same way and which are expected to need similar risk reduction measures. Since this method of classification depends on the distribution of the data, the study of any index evolution over time must maintain the ranges established in the initial analysis. 
Table 3. Resilience assessment: society's capacities, related emergency phases and questionnaire applied.

\begin{tabular}{|c|c|c|}
\hline $\begin{array}{l}\text { Society's } \\
\text { capacities }\end{array}$ & $\begin{array}{l}\text { Emergency management phases } \\
\text { (description based on US IOTWS, 2007) }\end{array}$ & Resilience questionnaire \\
\hline \multirow{3}{*}{$\begin{array}{l}\text { Coping } \\
\text { capacity }\end{array}$} & $\begin{array}{l}\text { Information and awareness. } \\
\text { Leadership and community } \\
\text { members are aware of hazards and } \\
\text { risk information is utilised when } \\
\text { making decisions. }\end{array}$ & $\begin{array}{l}\text { 1. Existence of social awareness } \\
\text { 2. Existence of institutional awareness }\end{array}$ \\
\hline & $\begin{array}{l}\text { Warning and evacuation. } \\
\text { Community is capable of receiving } \\
\text { notifications and alerts of coastal } \\
\text { hazards, warning at-risk populations, } \\
\text { and individuals acting on the alert. }\end{array}$ & $\begin{array}{l}\text { 3. Existence of tsunami Early Warning System } \\
\text { 4. Existence of evacuation routes } \\
\text { 5. Existence of maps/drawings with hazard areas and critical spots } \\
\text { 6. Development of evacuation drills in institutions and communities }\end{array}$ \\
\hline & $\begin{array}{l}\text { Emergency response. } \\
\text { Mechanisms and networks are } \\
\text { established and maintained to } \\
\text { respond quickly to coastal disasters } \\
\text { and address emergency needs at } \\
\text { the community level. }\end{array}$ & $\begin{array}{l}\text { 7. Proper functioning of the Municipal Commission of Civil Protection } \\
\text { 8. Existence of a contingency plan } \\
\text { 9. Existence of Communal Committees for risk management } \\
\text { 10. Existence of coordination networks at departmental/national levels } \\
\text { 11. Existence of sufficient emergency human resources }\end{array}$ \\
\hline $\begin{array}{l}\text { Recovery } \\
\text { capacity }\end{array}$ & $\begin{array}{l}\text { Disaster recovery. } \\
\text { Plans are in place prior to hazard } \\
\text { events that accelerate disaster } \\
\text { recovery, engage communities in the } \\
\text { recovery process, and minimise } \\
\text { negative environmental, social, and } \\
\text { economic impacts. }\end{array}$ & $\begin{array}{l}\text { 12. Existence of temporary shelters } \\
\text { 13. Existence of municipal funds to cover immediate expenses } \\
\text { 14. Existence of catastrophe insurance } \\
\text { 15. Existence of sufficient medical and public health human resources } \\
\text { 16. Existence of sufficient development human resources }\end{array}$ \\
\hline
\end{tabular}

As conducted by Greiving et al. (2006) and Jelínek et al. (2009), the risk is calculated through a risk matrix by combining the classes obtained for the hazard and the vulnerability indices, or hazard and sensitivity indices in the case of partial results. The sensitivity and vulnerability are calculated on the exposed elements; therefore, the exposure is implicitly incorporated into the matrix. Once the municipalities with higher risk values are identified, in other words those which are expected to have serious negative consequences due to the combination of the hazard scenario modelled and the vulnerability conditions, the calculation of the specific expected impacts at the local level is carried out. The different methods applied to the Western Coastal Plain of El Salvador are described in Sect. 2.3.3 together with the obtained results.

\subsubsection{Results and discussion}

The vulnerability results for the coastal area of El Salvador are analysed and mapped in Fig. 3. The municipalities are organised geographically within the graphs, thereby facilitating the comparison of numerical and cartographic results.

The sensitivity index numerical and cartographic results explain how sensitive the exposed municipalities are regarding the different dimensions. The sensitivity is represented through the graph columns and the colour code on the maps.
The identification of the causes that make each municipality more or less susceptible to the hazard is based on the sensitivity indicators, with the different colours within the columns representing the contribution of the different indicators to their index. For example, one can differentiate the reasons why two municipalities have similar socioeconomic sensitivity, identifying whether it is due to the potential loss of contribution to foreign trade or GDP. The results obtained will feed the risk reduction measures for each dimension.

The results of the resilience index at the national level allow an understanding, in a general and preliminary way, of the main weaknesses in emergency management, in order to design further detailed analyses to propose weaknessoriented site-specific corrective measures. The main shortcomings regarding the emergency phases can be identified and consequently tackled, both at the municipality level (e.g. Acajutla does not have temporary tsunami shelters) and transversally for a more coherent regional planning (e.g. the country lacks a tsunami insurance or a properly implemented tsunami EWS, although some respondents stated that the existing flooding warning procedures could be easily incorporated to the tsunami EWS), as shown in Fig. 4. Quantitative information for the indicators would nonetheless provide more detailed results to analyse the coastal municipalities in 


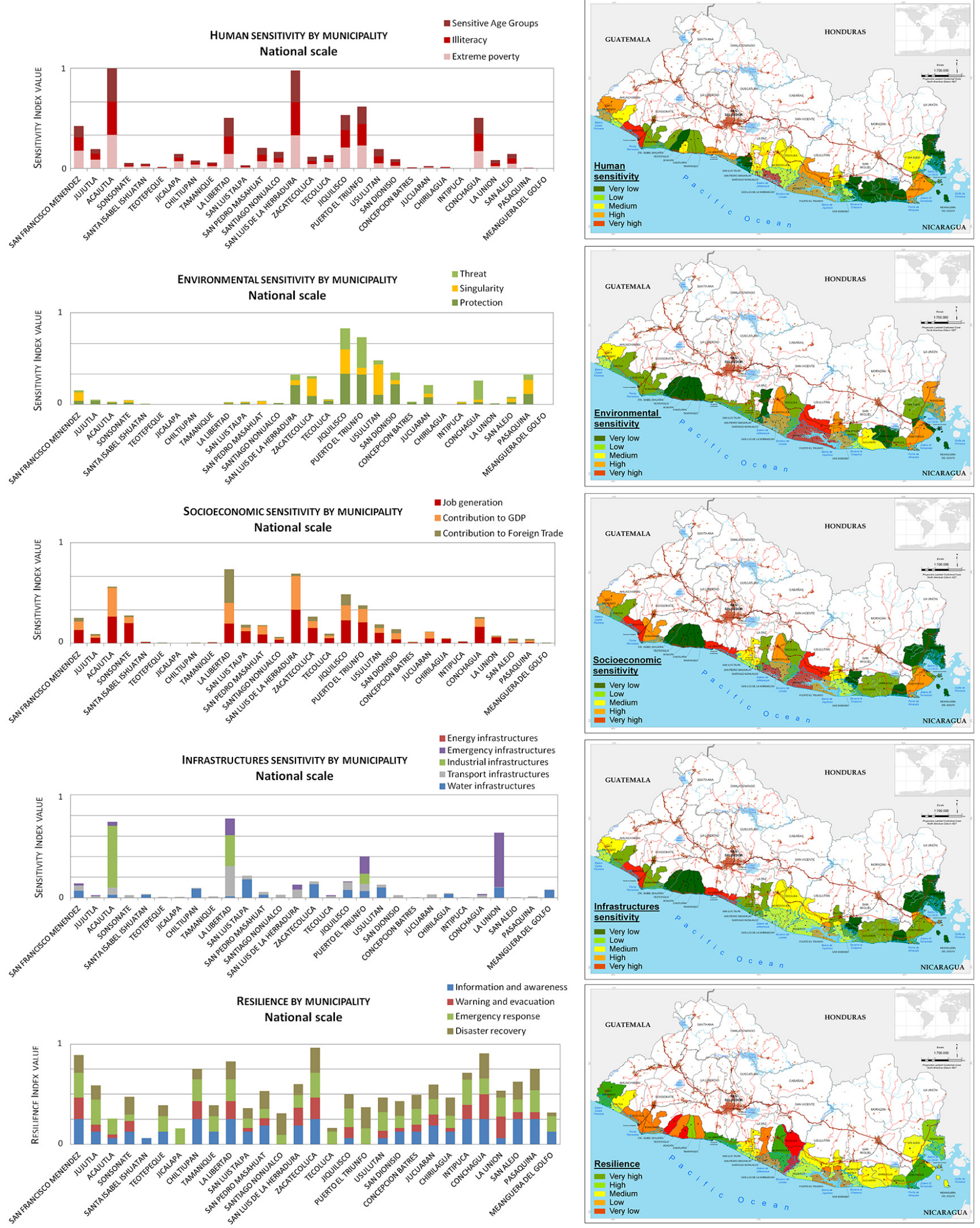

Figure 3. Vulnerability results for the El Salvadoran coastal area at the national scale by municipality: (from top to bottom) (i) human, (ii) environmental, (iii) socioeconomic and (iv) infrastructural sensitivity, and (v) community resilience. 


\section{RESiLIENCE QUESTIONNAIRE RESULTS FOR THE COASTAL AREA OF El SALVAdOR}

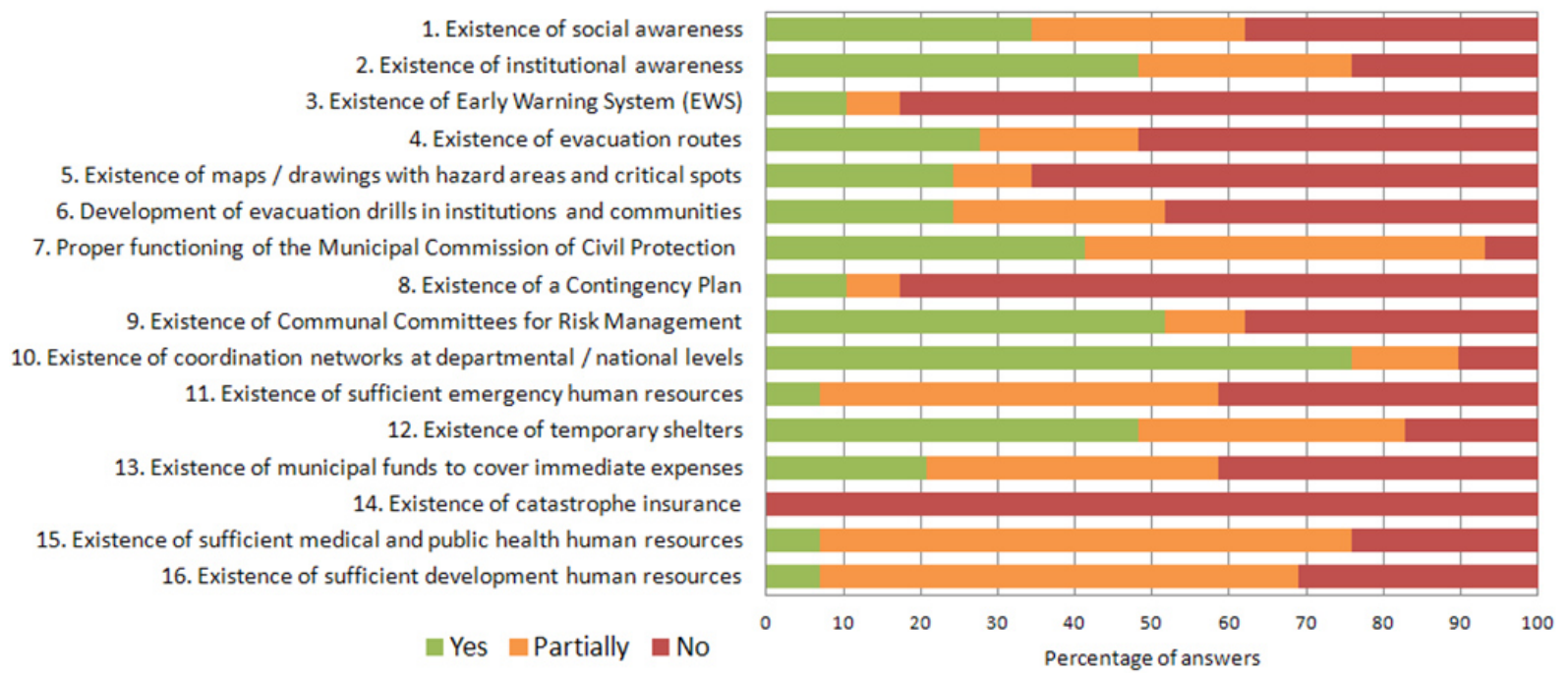

Figure 4. Resilience questionnaire results for tsunami hazard on the coastal area of El Salvador.

terms of, for instance, the number of temporary shelters or doctors by population density and municipality.

The importance of each indicator or variable and the critical role of some of them within the assessment have been considered through the weighted aggregation. Accordingly, in the case of resilience, coping capacity is weighted more than the recovery capacity due to the prioritisation of saving lives, and resilience is weighted less than sensitivity due to the use of more subjective information. The workshop made evident the difficulties in weighting the different resilience variables: the first impulse for almost everyone was to give higher weights to early warning system and evacuation routes; however, a lack of social awareness regarding evacuation (question 1) or a communication and coordination malfunction between the different warning responsible levels (questions $7,9,10$ ) could turn a tsunami warning ineffective. Regarding social awareness in the case of a local tsunami, a community informed and trained about the tsunami hazard would start evacuating just after feeling the earthquake, which could save valuable time before the warning is issued and, hopefully, lives.

The aggregated result (sensitivity or resilience) per se should not be understood as the final aim of the work, but the generation of information for the formulation of risk reduction measures; i.e. the assessments allow the identification of site-specific topics that should be managed before a tsunami event happens. In other words, and as an example, the resilience assessment identifies in which municipalities one should work on designing evacuation routes and in which ones the focus should be on social awareness or an early warning system. Similarly, the sensitivity results identify in which municipalities specific attention must be paid regarding the evacuation of critical buildings such as schools, hospitals, etc., where an alternative water supply for coastal communities with potential polluted wells must be planned, or where specific information and training campaigns must be designed for isolated areas or municipalities with a large amount of people with difficulties understanding a warning message.

The national risk assessment (Fig. 5c), obtained from the combination of hazard and vulnerability results (Fig. 5a and $b$, respectively), allowed for the identification of the critical areas in which a more detailed analysis is needed. The specific expected impacts have been calculated for the three local areas framed by black squares in the figure, with some of the results for the Western Coastal Plain being presented next. The calculation of the extent of the negative consequences (damage levels) varies according to the available methodologies in literature and information, not being defined for every dimension or exposed element in a homogeneous way. The specific results, which differ in format and scope, cover the different dimensions as well, providing essential knowledge for risk management and the formulation of adequate risk reduction measures.

The zoning for the expected human damage in the Western Coastal Plain (Fig. 6a), is calculated through the combination of tsunami drag (based on Jonkman et al., 2008) and human sensitivity. An overall 20429 persons are exposed to this tsunami event, $75 \%$ of them being located in very high and high human damage areas. This information is very useful for evacuation planning, as the critical areas in terms of hazard, exposure and sensitivity are identified. One could argue that evacuation planning as well as other type of measures, such as the identification of evacuation routes and shelter areas, could proceed without such detailed information; however, the more information is collected, the better 

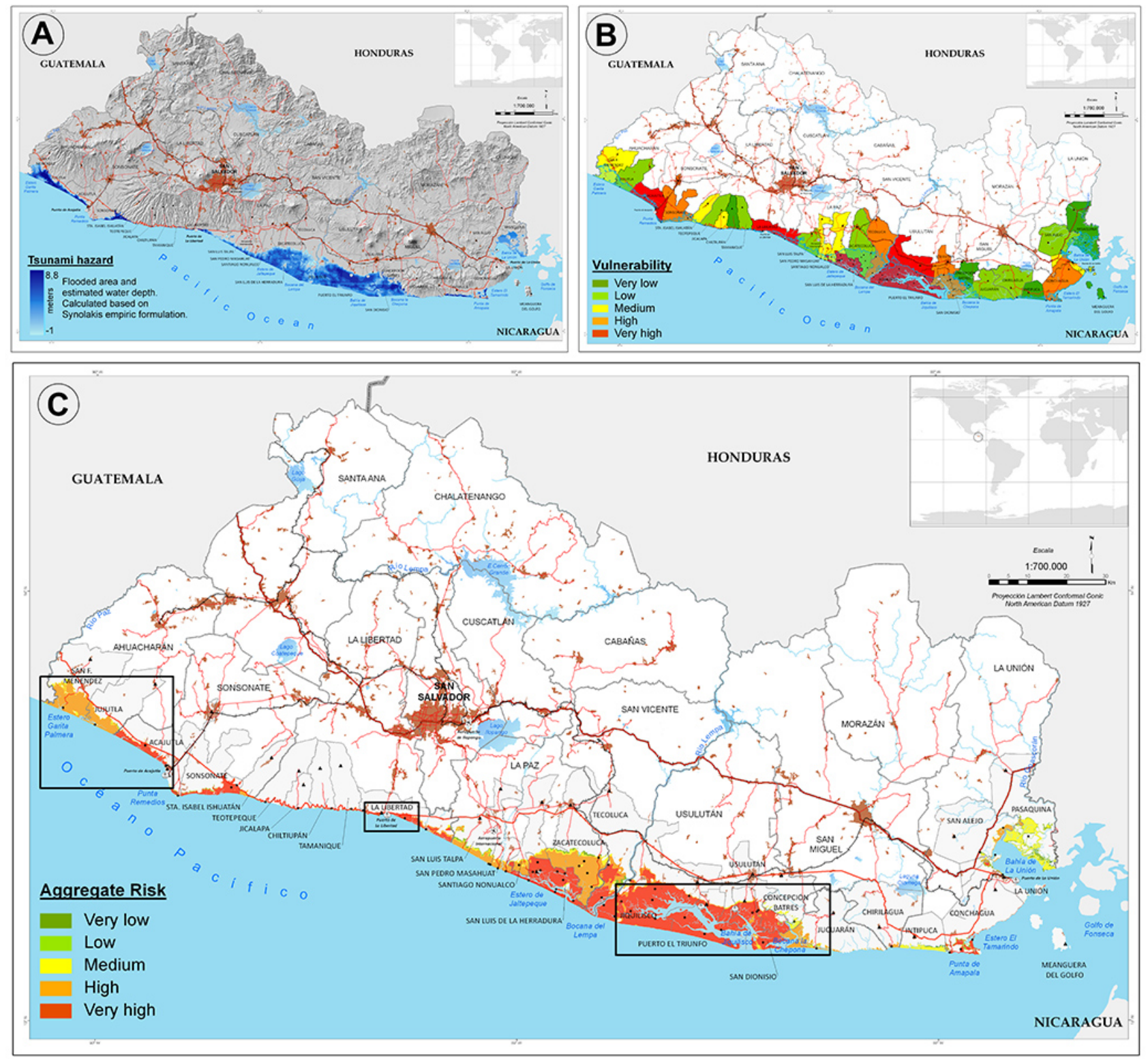

Figure 5. National tsunami risk assessment in El Salvador: (a) hazard assessment: flooded area and water depth results; (b) vulnerability assessment by municipality including the human, environmental, socioeconomic and infrastructural dimensions; (c) risk assessment combining hazard and vulnerability results via the risk matrix (the areas framed by black squares show the local studies carried out; from left to right: Western Coastal Plain, La Libertad municipality and Jiquilisco Bay).

management options can be applied. Knowing the evacuation speed of the population, which can depend on the age, disabilities, etc., will allow modelling the evacuation in order to identify critical areas where people would not be able to reach a shelter before the tsunami reaches the coast. Knowing where the sensitive population in terms of evacuation is located facilitates planning alternative measures for them.

Figure $6 \mathrm{~b}$ shows the number of buildings exposed to the tsunami event by census segment (blue colour code) and the expected impacts on buildings (pie charts) calculated through the adaptation of the SCHEMA methodology to El Salvador based on water depth and building materials (Tinti et al., 2011). In total, 6557 buildings are exposed in the Western Coastal Plain, $26 \%$ of them being included among the important damage and partial failure classes.

The area and location of ecosystems and related ecosystem services that would be affected by a potential event, as well as the local communities depending on them have been identified. The area, number of jobs and economic contribution to be lost for the different socioeconomic activities exposed to the hazard is provided in Fig. 7a. It shows that the largest area of socioeconomic activity that would be lost 

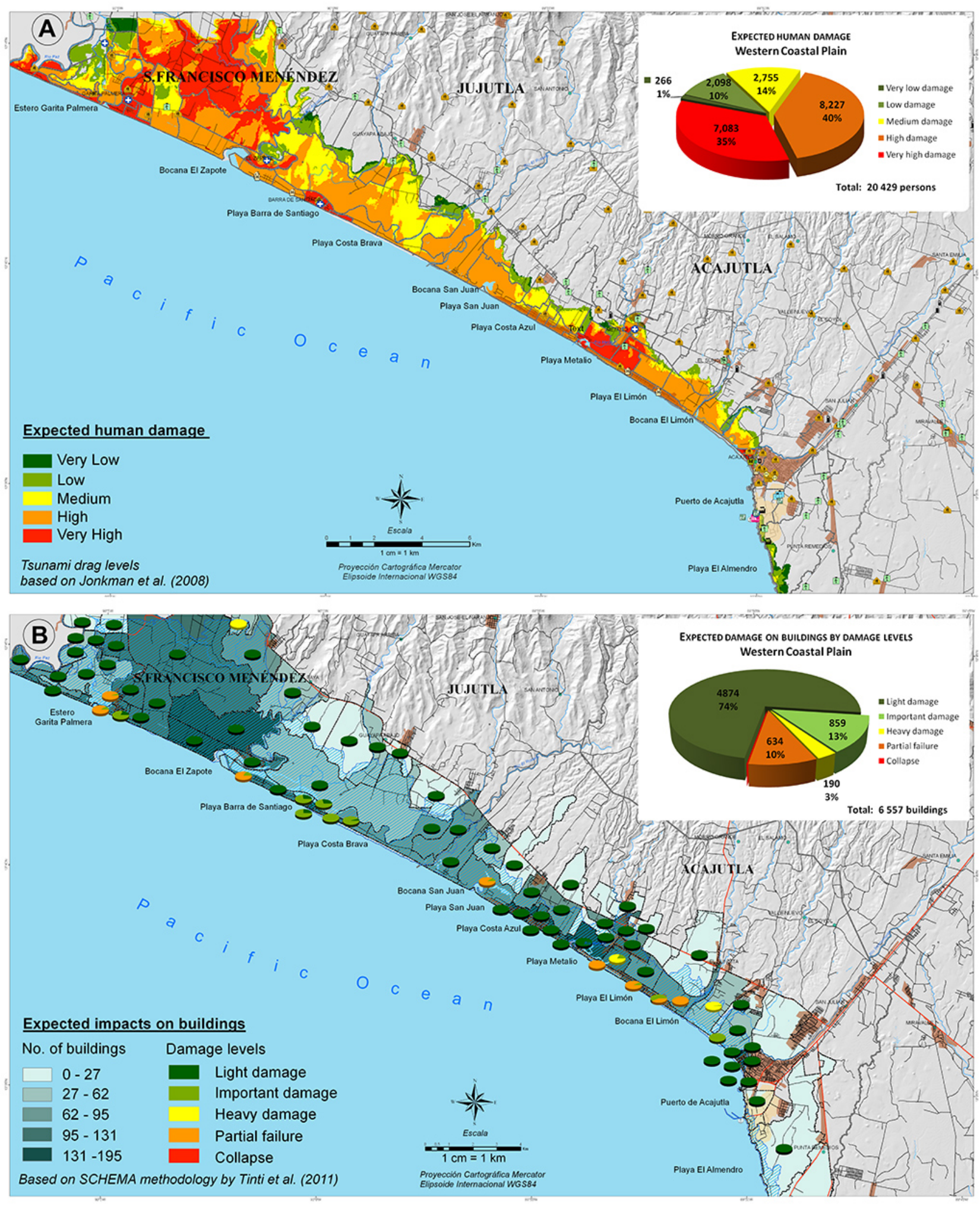

Figure 6. Expected impacts in the Western Coastal Plain of El Salvador: (a) zoning for expected human damage, and (b) expected impacts on buildings by census segment. 


\section{A. EXPECTED IMPACTS ON SOCIOECONOMIC ACTIVITIES}
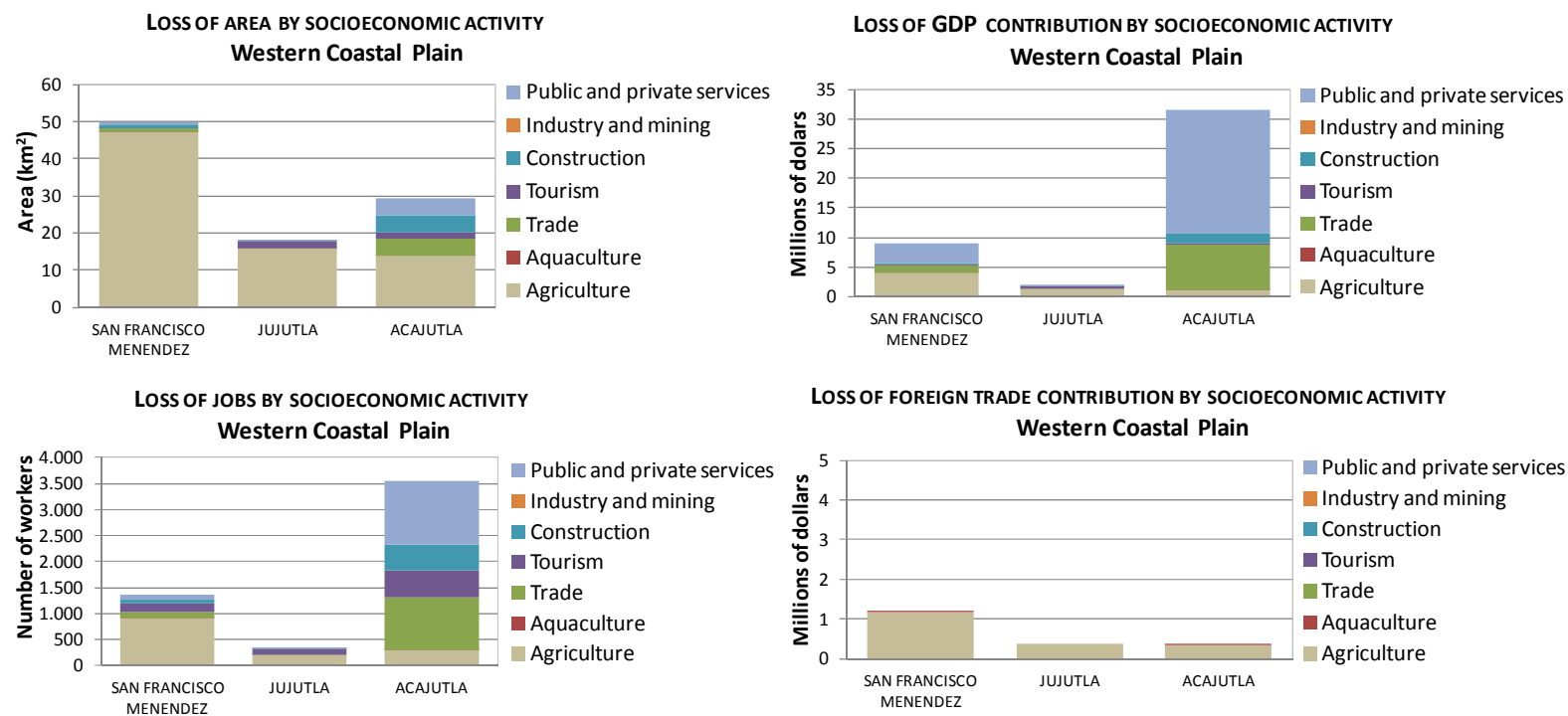

\section{B. EXPECTED IMPACTS ON INFRASTRUCTURES}

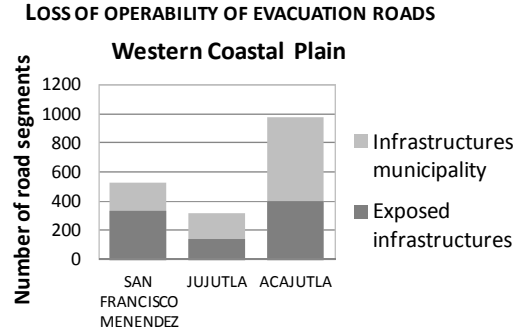

LOSS OF LONG-TERM WATER SUPPLY (WELLS) Western Coastal Plain

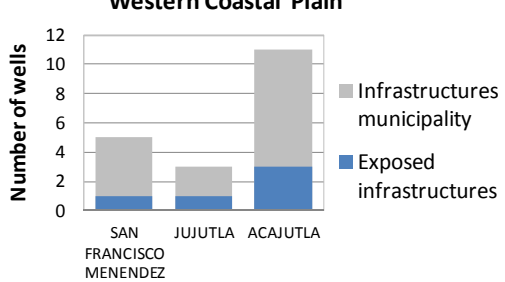

POTENTIAL INDUSTRIAL CASCADING RISK EFFECTS

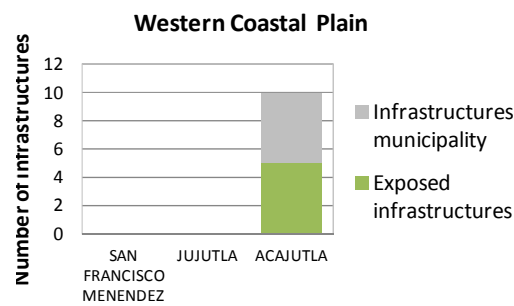

POTENTIAL INDUSTRIAL CASCADING RISK EFFECTS

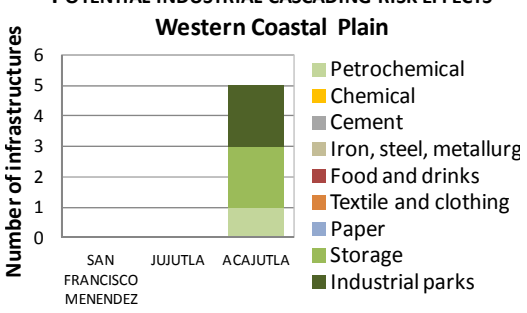

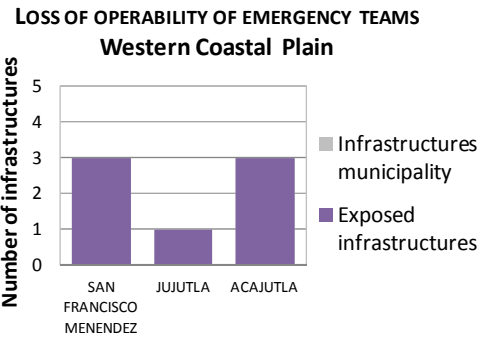

LOSS OF OPERABILITY OF EMERGENCY TEAMS

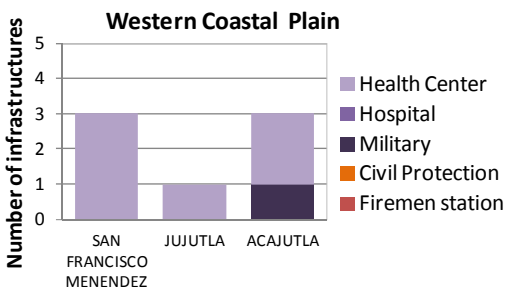

Figure 7. Expected impacts in the Western Coastal Plain of El Salvador: (a) impacts on socioeconomic activities, and (b) impacts on infrastructures.

is mainly agricultural land in the three municipalities; this implies practically the entire expected loss of contribution to foreign trade. The other smaller exposed socioeconomic area is dedicated to tourism, trade, construction and services, mainly in urban areas, and especially in Acajutla municipality. This small multi-activity area would imply the biggest impacts in terms of loss of jobs and loss of contribution to GDP.
Figure $7 \mathrm{~b}$ shows some examples of the analysis of impacts on infrastructures for the Western Coastal Plain, based on the identification and location of the sensitive infrastructures potentially affected, implying various consequences to the population, such as the reduction of possible evacuation roads, the potential pollution of wells hindering long-term supply to coastal communities, the affect on dangerous/hazardous industrial infrastructures that could worsen the tsunami impacts, or the exposure of all the emergency infrastructures 

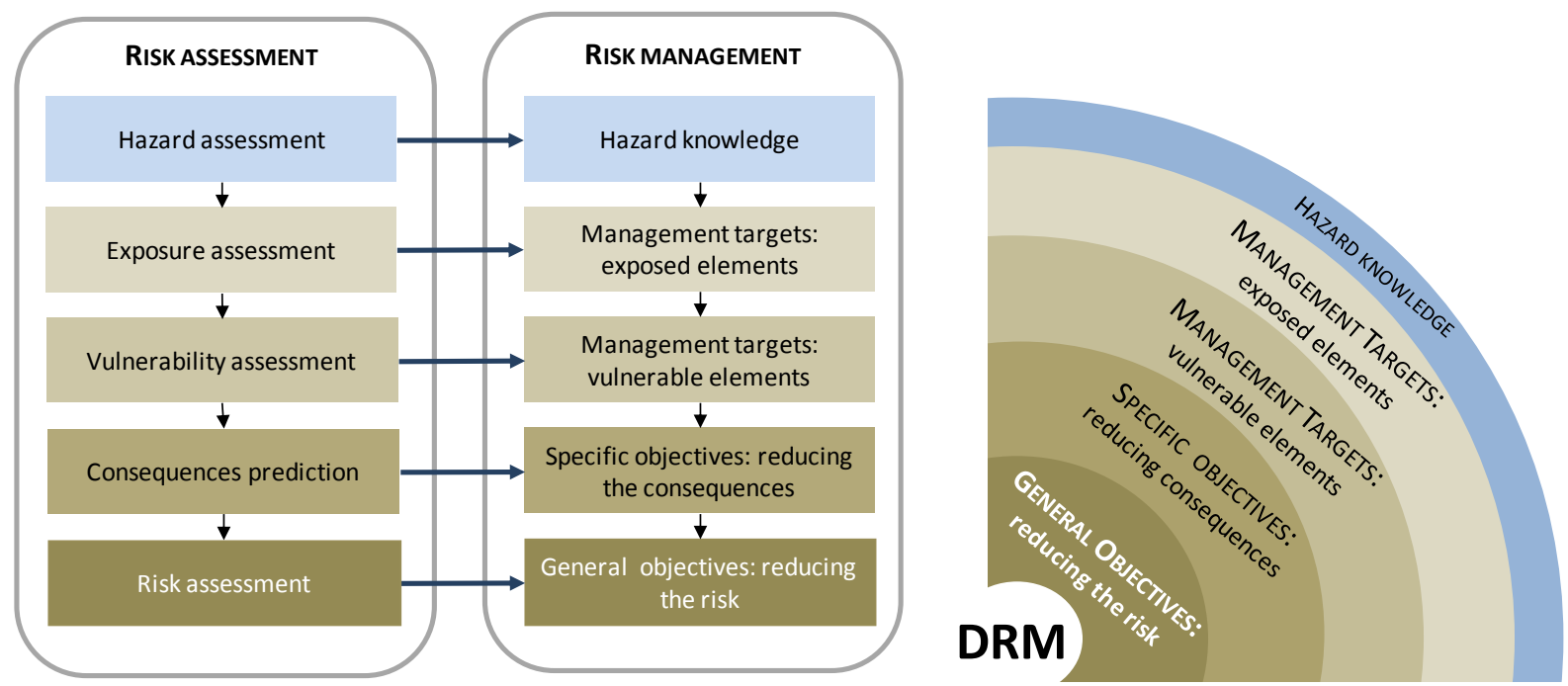

Figure 8. Left: translating vulnerability and risk results into a management framework. Right: disaster risk management (DRM) dartboard framework.

present in the study area, which probably will not be able to help the population in case of a tsunami event.

\section{Tsunami risk management: application to El Salvador}

Scientific risk assessment studies are frequently characterised by a linear structure that goes from the hazard and vulnerability assessments to the final risk calculation, very few of them providing specific risk reduction options. This linear structure and the lack of a clear and straightforward link with the disaster risk management (DRM) may generate a lack of connection between the authorities' decisionmaking and the technical results obtained from the risk assessment. This section focuses on how to enhance the value of the gathered knowledge to translate the results into something closer to the management options the decision-maker needs. Figure 8 shows how the risk assessment process can directly feed the various steps within the risk management process. Once the connection between both processes is identified, the structures of the studies are reoriented in order to have the DRM as the main goal to achieve. The scheme on the right, in a dartboard shape, shows that the closer a study arrives to the centre of the dartboard, the more useful it becomes for the managers.

Based on the results of the national and local risk assessment carried out for El Salvador and the main expected impacts due to the modelled tsunami event, different adaptation and mitigation measures can be proposed. It is here understood that mitigation measures aim to reduce the hazard's effect on the coastal system, while adaptation measures basically aim to reduce the vulnerability by reducing the sensitivity or enhancing the resilience-identified shortcomings. The overlap of mitigation and adaptation measures on the exposure component is due to territorial and time factors - i.e. a risk reduction measure aimed at reducing the exposure will be a mitigation measure if it intends to change the location of existing elements, but can be considered an adaptation measure if it intends to plan the future location of elements so as to limit as much as possible their presence in the area.

DRM must be site-specific and needs to be detailed and individually applied to the different study areas. Fig. 9 shows an example of general planning structure based on some of the results presented. The main goal is the DRM in the centre of the figure, and to achieve it different tasks are needed: (i) knowledge acquisition about the hazard; (ii) identification and location of the exposed elements of that hazard to be considered; (iii) from the exposed ones, analysis of the vulnerable elements as management targets; (iv) formulation of DRM-specific objectives to reduce the expected negative consequences on each dimension; and (v) DRM general objectives to guide the management of the study area. Focusing for example on the human dimension in Fig. 9, the general objective is reducing human risk by ensuring effective evacuation, this can be achieved by minimising the population evacuation and reaction time. Table 4 shows the translation of the tsunami risk results obtained in Acajutla municipality into risk reduction measures by following the steps suggested in Fig. 8. According to this approach, specific risk reduction measures are proposed to address each of the identified impacts in every dimension. However, it is normally politically and economically difficult for a country to implement them all, a prioritisation of measures being required.

DRM, as a complex process, deals with a huge amount of information including different kinds of data on hazards, exposed elements, dimensions, vulnerabilities, spatiotemporal scales, specific problems, scenarios, stakeholders, 


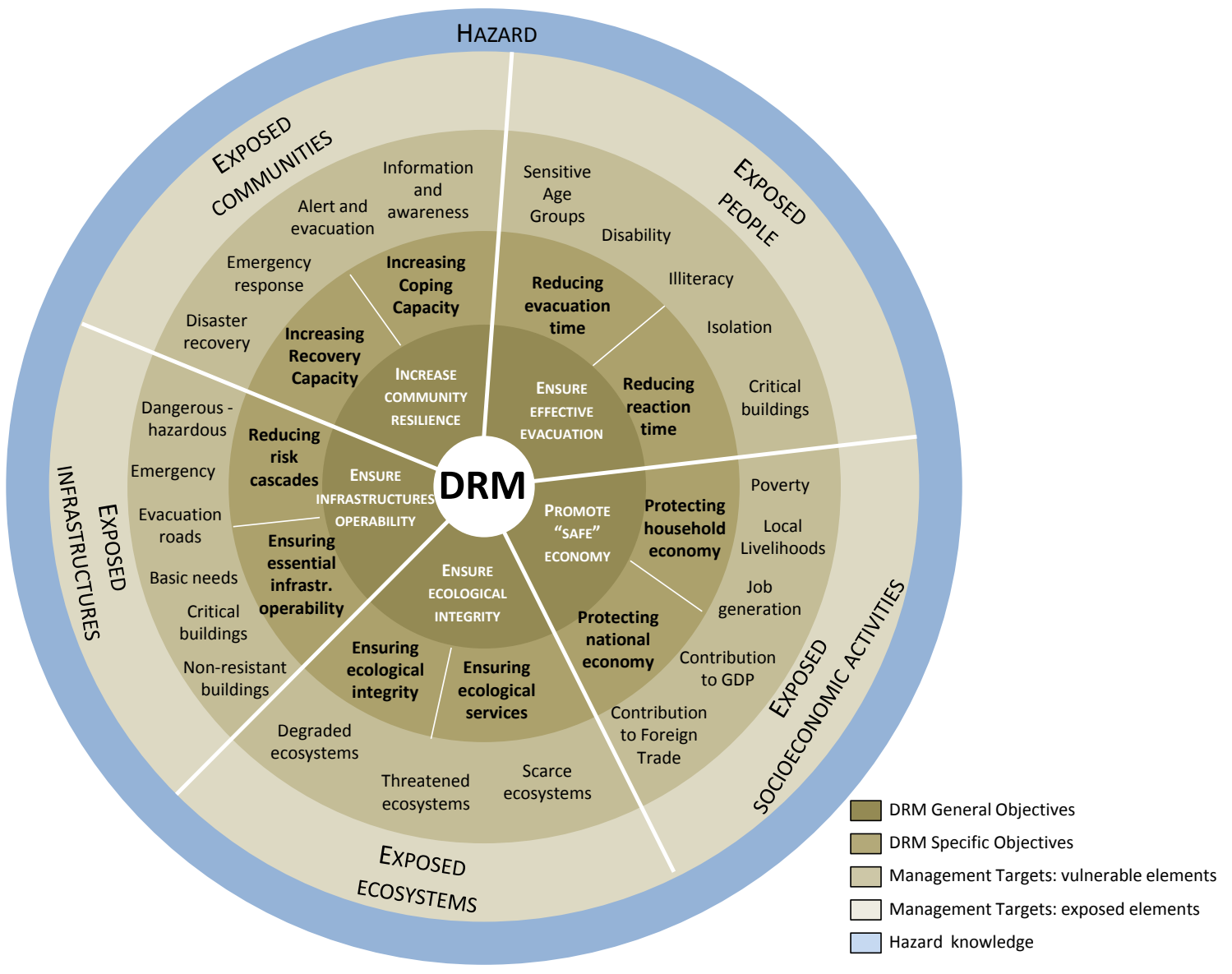

Figure 9. Example of risk management framework for tsunami hazard in El Salvador.

governance, resilience, emergency protocols, early warning systems, etc. This information must be properly prioritised in order to optimise the management process, select the most urgent and relevant issues to solve and once the first objectives have been fulfilled, address the next ones. Therefore, after the definition of the risk management structure, the next task would be identifying the key factors affecting or controlling the system (i.e. leverage points) as they can be used to bring about major changes in the system with minimum effort (Martín García, 2006), the system dynamics being a potential tool to achieve this objective (Sterman, 2002, 2006; Meadows, 2008).

Figure 10a shows the system dynamics modelled for the analysis of tsunami impacts in Acajutla based on the participatory contribution of the various technicians from MARN and IH Cantabria. The impact of a tsunami event on the exposed and vulnerable elements (capital letters and blue font text, respectively) produce different cause-effect relationships and feedback loops (arrows) within the system generating the various negative consequences under study (text in boxes). These causal relationships show some kind of relevance roles and priorities between the elements in terms of management, which means that by working on some of them, results can be obtained on the others. The feedback loops between the final consequences highlight those that can worsen other impacts in the same or other dimensions and that, consequently, should be tackled first. For example, the generation of risk-cascading effects and the loss of infrastructures' operability generate human casualties and environmental impacts; analogously, the loss of ecological integrity reduces the capability of generating ecological services, which affects the socioeconomic dimension.

Understanding the behaviour of the system and the interrelationships between the elements allows for the proposal of different management scenarios to understand the effects of the decision-making and to optimise the DRM. Fig. $10 \mathrm{~b}$ shows the causal relationships and tsunami impacts partially tackled by three risk reduction measures (orange boxes) proposed here: (i) promotion of population information and awareness campaigns tailored to the local sensitivity characteristics; (ii) protection and reforestation of mangroves; (iii) relocation or reinforcement of the seven critical buildings, and one dangerous-hazardous and three emergency infrastructures identified. It also shows how these three measures affect various causal relationships and feedbacks between the elements, and allow obtaining parallel extra results to those 
Table 4. Translation of human risk results into DRM options (Acajutla, Western Coastal Plain, El Salvador). Further information provided by González-Riancho et al. (2013).

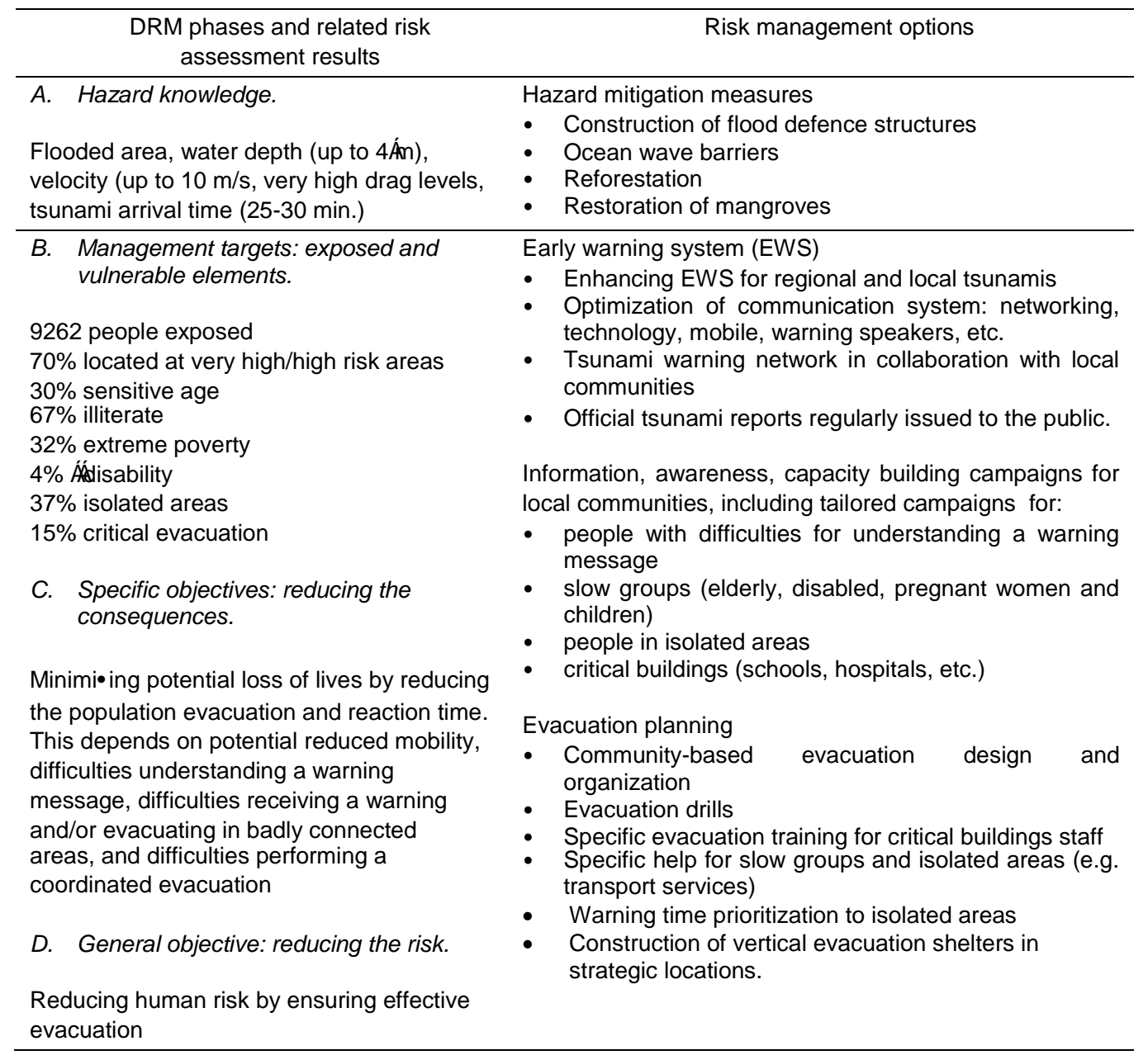

that were originally planned. The orange arrows represent the flows set in motion due to the risk reduction measure, while the yellow boxes show the consequences that are affected or improved somehow by these flows.

This example aims to show that one single action may have many results in complex systems, which is an interesting idea to bring forward in risk management. Working with complex systems is complicated, as many aspects, dimensions and variables should be considered and dealt with. However, once the system is understood, one can take advantage of this complexity to generate better results with less effort. Therefore, the understanding of complex systems allows for optimising the effort and getting the best results from the management options applied.

Working with scenarios provides the opportunity to understand the current system, predict the consequences of different plausible management options and, consequently, promote an adequate risk reduction plan for the studied area. It can be therefore a dynamic assessment of policy options and their response to existing feedback loops.

\section{Conclusions}

Advances in the understanding and prediction of tsunami impacts allow for the development of risk reduction strategies for tsunami-prone areas. Based on existing vulnerability and risk frameworks and approaches, the main expected contribution is to provide a straightforward method to facilitate their implementation. The method deals with the complexity and variability of CHANS by means of an integral approach to cover the entire process from the risk assessment to the risk management; an integrated approach to combine and aggregate the information stemming from the different dimensions; and a dynamic and scale-dependent approach to integrate the spatiotemporal variability considerations.

Risk assessment at the national level aims at comparing and prioritising municipalities in terms of risk reduction 


\section{A. SYSTEM DYNAMICS FOR THE ANALYSIS OF TSUNAMI IMPACTS}

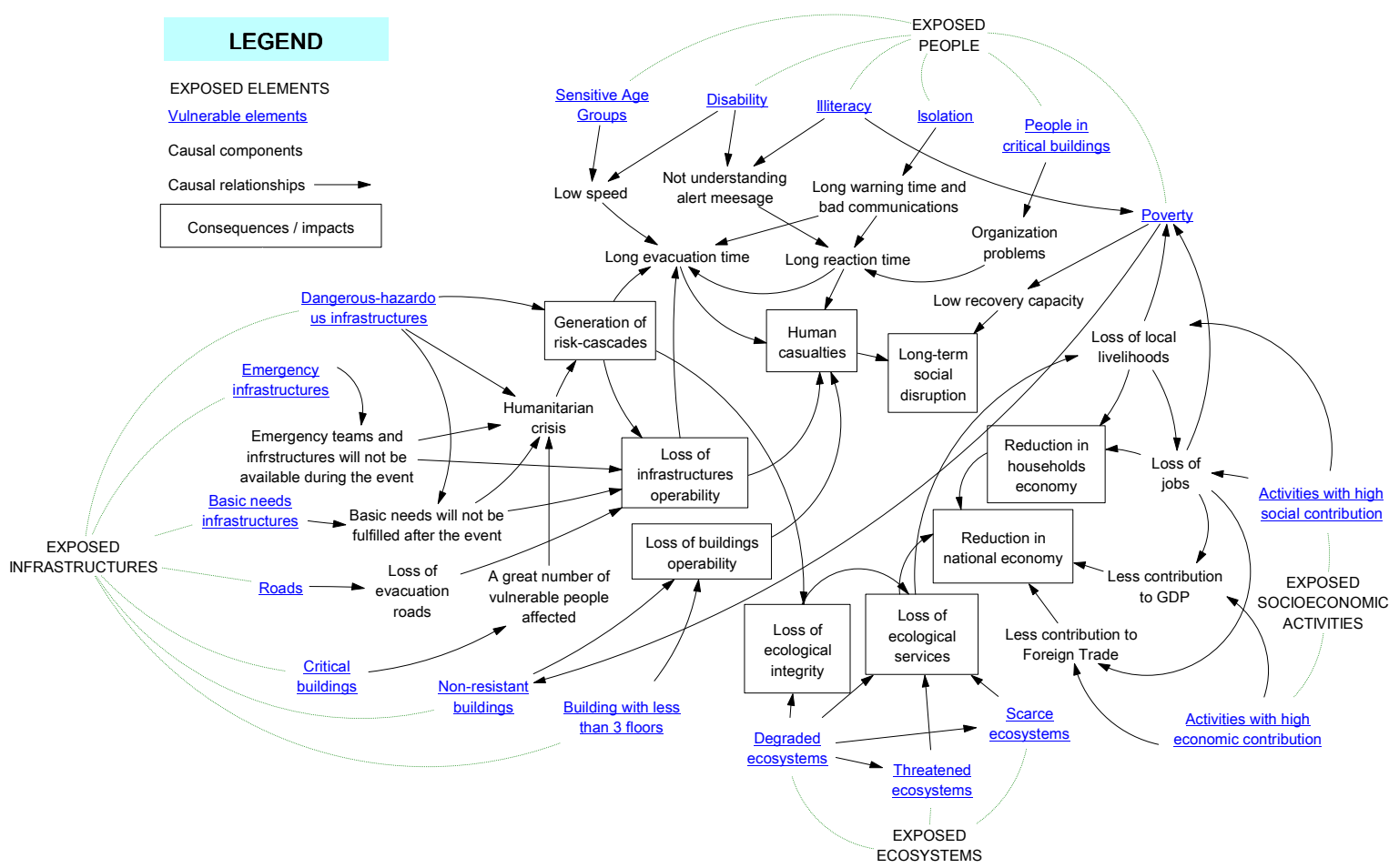

\section{B. CAUSAL RELATIONSHIPS AFFECTED BY POTENTIAL RISK REDUCTION MESURES}

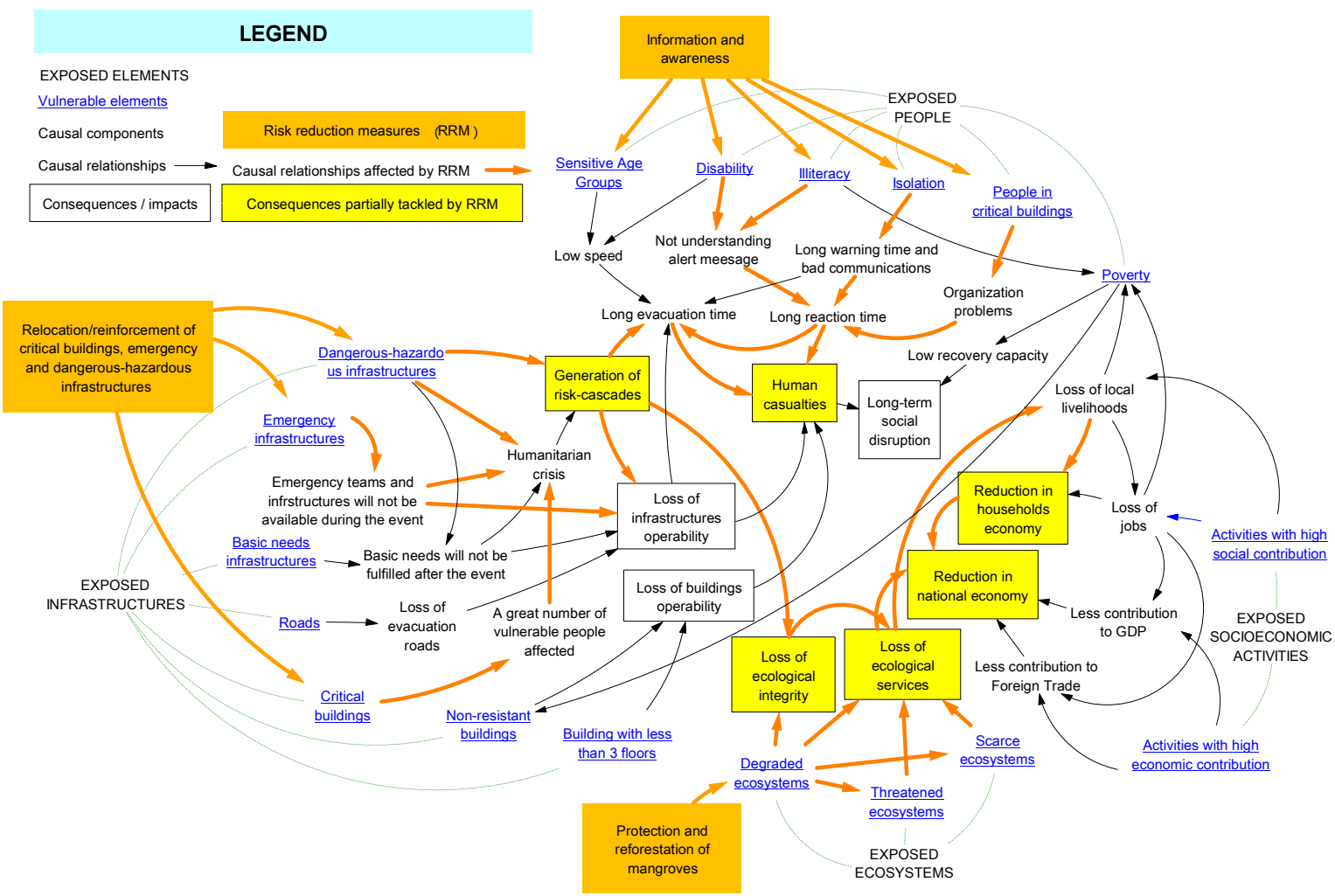

Figure 10. (a) System dynamics for the analysis of tsunami impacts in El Salvador; (b) causal relationships and tsunami impacts affected by potential risk reduction measures (Vensim ${ }^{\circledR}$ Software). 
efforts (see Fig. 5), while the assessment at the local level of the prioritised municipalities is aimed at calculating the specific expected impacts by dimension (see Figs. 6 and 7).

The deterministic hazard assessment based on propagation models for earthquake-generated tsunamis provided different hazard maps along the coast of El Salvador. This permitted the identification of the main tsunami flood-prone areas, that is, the Western Coastal Plain and the coastal stretch between La Libertad and Jucuaran municipalities, with the Lempa river mouth and Jiquilisco and Jaltepeque wetlands being especially relevant in terms of flooded area. The proposed exposure and vulnerability mixed indicator approach has proved to be useful to identify and locate the elements in the hazard area, as well as to measure the human, environmental, socioeconomic and infrastructural characteristics that make the municipalities more susceptible to the selected impacts.

The qualitative resilience assessment identified (through a short questionnaire) the degree of organisation and response within a community in case of an emergency. The analysis of a single municipality may not require a resilience index (i.e. numerical); however, when a comparison between municipalities is required (which was the aim of the national assessment), the resilience index seems to be a possible approach to have a general idea of the state of each municipality in terms of their preparedness and emergency management in order to design further detailed analyses to propose weakness-oriented, site-specific corrective measures.

A clear connection to translate the vulnerability and risk assessments into risk reduction measures is offered, trying to bridge the gap between science and management for the tsunami hazard. The risk assessment process directly feeds the required information to develop the risk management process, by reorienting its usual linear structure in order to have the DRM as the main goal to achieve. The approach, together with system dynamics modelling, facilitates the identification and prioritisation of ways to reduce the sensitivity of municipalities regarding various dimensions and to enhance the resilience of communities. Regarding the practical application of the RRM to the case study of El Salvador, and based on the risk results presented above, several measures are already being developed by the MARN, such as public tsunami hazard bulletins and monthly reports, information and awareness campaigns for local communities, a network of local observers to warn the communities in collaboration with the Ministry and Civil Protection, and communitybased evacuation planning (further information is provided by González-Riancho et al., 2013).

A dynamic model to update the risk results is expected to be incorporated into the methodology as an effective tool for adaptive risk management. It is intended to gradually update the set of indicators, as the risk reduction measures are being implemented, allowing the systematic modification of the exposure, vulnerability and risk results and the understanding and utilising of the interrelation and feedback loops controlling the behaviour of the coupled human and natural system.

Acknowledgements. We would like to thank the Spanish Agency for International Development Cooperation (AECID) for funding and supporting the project framing this research, called Evaluación del Riesgo por tsunami en la costa de El Salvador (Fase I: Peligrosidad, Fase II: Vulnerabilidad y Riesgo) and developed during the period 2009-2012; and the Ministry of Environment and Natural Resources (MARN) of El Salvador for our fruitful collaboration. We also thank the European project NEARToWARN (Near-field Tsunami Warning).

Edited by: I. Didenkulova

Reviewed by: A. Armigliato and two anonymous referees

\section{References}

Aboelata, M. and Bowles, D. S.: LIFESim: a model for estimating dam failure life loss, Draft Report to Institute for Water Resources, US Army Corps of Engineers and Australian National Committee on Large Dams, Institute for Dam Safety Risk Management, Utah State University, Logan, Utah, 2005.

Alliance Development Works in collaboration with United Nations University and The Nature Conservancy: World Risk Report 2012, Alliance Development Works, ISBN 978-3-9814495-0-3, Berlin, 2012.

Álvarez-Gómez, J. A., Aniel-Quiroga, Í., Gutiérrez-Gutiérrez, O. Q., Larreynaga, J., González, M., Castro, M., Gavidia, F., Aguirre-Ayerbe, I., González-Riancho, P., and Carreño, E.: Tsunami hazard assessment in El Salvador, Central America, from seismic sources through flooding numerical models., Nat. Hazards Earth Syst. Sci., 13, 2927-2939, doi:10.5194/nhess-132927-2013, 2013.

Alvear Brito, J. G. and Cruz D’Howitt, M. A.: Elaboración de un mapa de accesibilidad y modelo de evacuación ante una eventual ocurrencia de tsunami en las ciudades de Salinas y Bahía de Caráquez, mediante herramientas geoinformáticas, Revista Geoespacial, 5, 1-15, 2009 (in Spanish).

Birkmann, J.: Measuring vulnerability to promote disaster-resilient societies: conceptual frameworks and definitions, in: Measuring Vulnerability to Natural Hazards vol. 1, United Nations University Press, Tokyo, Japan, 9-54, 2006.

Birkmann, J., Cardona, O. D., Carreño, M. L., Barbat, A. H., Pelling, M., Schneiderbauer, S., Kienberger, S., Keiler, M., Alexander, D., Zeil, P., and Welle, T.: Framing vulnerability, risk and societal responses: the MOVE framework, Nat. Hazards, 67, 193-211, 2013.

Clerveaux, V., Katada, T., and Hosoi, K.: Tsunami scenario simulator: a tool for ensuring effective disaster management and coastal evacuation in a multilanguage society, Sci. Tsunami Haz., 27, 48-71, 2008.

Cruz, A. M., Franchello, G., and Krausmann, E.: Assessment of Tsunami Risk to an Oil Refinery in Southern Italy, Tsunami Risk ANd Strategies For the European Region (TRANSFER Project), available at: http://www.transferproject.eu (last access: 18 March 2014), 2009. 
Cutter, S. L., Barnes, L., Berry, M., and Burton, C.: A place-based model for understanding community resilience to natural disasters, Gobal Environ. Change, 18, 598-606, 2008.

Dall'Osso, F., Gonella, M., Gabbianelli, G., Withycombe, G., and Dominey-Howes, D.: Assessing the vulnerability of buildings to tsunami in Sydney, Nat. Hazards Earth Syst. Sci., 9, 2015-2026, doi:10.5194/nhess-9-2015-2009, 2009.

Damm, M.: Mapping Social-Ecological Vulnerability to Flooding. Graduate Research Series, Ph.D. Dissertations, Publication Series of UNU-EHS Vol. 3, ISBN: 978-3-939923-46-6. United Nations University - Institute for Environment and Human Security (UNU-EHS), Bonn, 2010

EC (European Commission): Risk Assessment and Mapping Guidelines for Disaster Management, Staff Working Paper SEC(2010) 1626 final, European Commission, Brussels, 2010.

ECLAC (Economic Commission for Latin America and the Caribbean): Handbook for Estimating the Socio-economic and Environmental Effects of Disasters, ECLAC, Mexico, available at: http://www.eclac.cl/cgi-bin/getProd.asp?xml/publicaciones/ $\mathrm{xml} / 4 / 12774 / \mathrm{P} 12774 . x \mathrm{ml} \& \mathrm{xsl}=/ \mathrm{mexico} / \mathrm{tpl}-\mathrm{i} / \mathrm{p} 9 \mathrm{f} . \mathrm{xs} l \ \& b a s e=$ /mexico/tpl/top-bottom.xsl (last access: 18 March 2014), 2003.

Fletcher, W. J.: The application of qualitative risk assessment methodology to prioritize issues for fisheries management, ICES J. Mar. Sci., 62, 1576-1587, 2005.

Fundación-Terram: Impactos ambientales del terremoto y tsunami en Chile, las réplicas ocultas del 27F, Santiago de Chile, Fundación-Terram, 2012.

González-Riancho, P., Aguirre-Ayerbe, I., Aniel-Quiroga, I., Abad, S., González, M., Larreynaga, J., Gavidia, F., Gutiérrez, O. Q., Álvarez-Gómez, J. A., and Medina, R.: Tsunami evacuation modelling as a tool for risk reduction: application to the coastal area of El Salvador, Nat. Hazards Earth Syst. Sci., 13, 32493270, doi:10.5194/nhess-13-3249-2013, 2013.

Goseberg, N. and Schlurmann, T.: Tsunami Hazard Mapping and Risk Assessment for the City Of Padang/West Sumatra, LastMile-Evacuation Project, Conference: Disaster Risk Reduction for Natural Hazards: Putting Research into Practice, London, available at: http://www.ucl.ac.uk/drrconference/presentations/ TSchlurmann.pdf (last access: 18 March 2014), 2009.

Greiving, S., Fleischhauer, M., and Lückenkötter, J.: A methodology for an integrated risk assessment of spatially relevant hazards, J. Environ. Plann. Man., 49, 1-19, doi:10.1080/09640560500372800, 2006.

Grezio, A., Gasparini, P., Marzocchi, W., Patera, A., and Tinti, S.: Tsunami risk assessments in Messina, Sicily - Italy, Nat. Hazards Earth Syst. Sci., 12, 151-163, doi:10.5194/nhess-12-151-2012, 2012.

Harbitz, C. B., Glimsdal, S., Bazin, S., Zamora, N., Løvholt, F., Bungum, H., Smebye, H., Gauera, P., and Kjekstad, O.: Tsunami hazard in the Caribbean: regional exposure derived from credible worst case scenarios, Cont. Shelf Res., 38, 1-23, doi:10.1016/j.csr.2012.02.006, 2012.

IH Cantabria-MARN: Instituto de Hidráulica Ambiental IH Cantabria, Ministerio de Medio Ambiente y Recursos Naturales de El Salvador MARN: Catálogo de Peligrosidad debida a la inundación por Tsunami en la costa de El Salvador, Spanish Agency for International Development Cooperation (AECID), available at: http://www.ihcantabria.com/es/ proyectos-id/item/839-tsunami-hazard-el-salvador (last access: 18 March 2014), 2010 (in Spanish).

IH Cantabria-MARN: Instituto de Hidráulica Ambiental IH Cantabria, Ministerio de Medio Ambiente y Recursos Naturales de El Salvador MARN: Catálogo de Vulnerabilidad y Riesgo debido a la inundación por Tsunami en la costa de El Salvador, Spanish Agency for International Development Cooperation (AECID), available at: http://www.ihcantabria.com/es/ proyectos-id/item/843-tsunami-vulnerability-risk-el-salvador (last access: 18 March 2014), 2012 (in Spanish).

ISO 31010:2009: Risk Management - Risk Assessment Techniques. International Electrotechnical Commission/International Organization for Standardization. IEC/ISO, available at: http://www.iso.org/iso/home/store/catalogue_tc/catalogue_ detail.htm?csnumber=51073 (last access: 18 March 2014), 2009.

Jelínek, R., Eckert, S., Zeug, G., and Krausmann, E.: Tsunami Vulnerability and Risk Analysis Applied to the City of Alexandria, Egypt, Tsunami Risk ANd Strategies For the European Region (TRANSFER Project), available at: http://www.transferproject. eu (last access: 18 March 2014), 2009.

Jenks, G. F.: The data model concept in statistical mapping, Int. Yearbook Cartogr., 7, 186-190, 1967.

Jonkman, S. N., Vrijling, J. K., and Vrouwenvelder, A. C. W. M.: Methods for the estimation of loss of life due to floods: a literature review and a proposal for a new method, Nat. Hazards, 46, 353-389, doi:10.1007/s11069-008-9227-5, 2008.

Koeri: Istanbul Test Area and the Marmara Sea, Tsunami Risk and Loss Assessment, Tsunami Risk ANd Strategies For the European Region (TRANSFER Project), available at: http://www. transferproject.eu (last access: 18 March 2014), 2009.

Kolen, B., Maaskant, B., Helsloot, I., and Thonus, B.: EvacuAid: a probabilistic evacuation model to determine the expected loss of life for different mass evacuation strategies, in: Proceedings of the International Conference on Emergency Preparedness: the Challenges of Mass Evacuation, edited by: Albores, P., Aston CRISIS Centre, Aston Business School, Aston University, Birmingham, UK, 21-23 September 2010, 33-43, 2010.

Koshimura, S., Katada, T., Mofjeld, H. O., and Kawata, Y.: A method for estimating casualties due to the tsunami inundation flow, Nat. Hazards, 39, 265-274, doi:10.1007/s11069-006-00275, 2006.

LeVeque, R. J., George D. L., and Berger, M. J.: Tsunami modelling with adaptively refined finite volume methods, Acta Numerica, 20, 211-289, doi:10.1017/S0962492911000043, 2011.

Liu, J., Dietz, T., Carpenter, S. R., Folke, C., Alberti, M., Redman, C. L., Schneider, S. H., Ostrom, E., Pell, A. N., Lubchenco, J., Taylor, W. W., Deadman, Z. O. P., Kratz, T., and Provencher, W.: Coupled Human and Natural Systems, Ambio, 36, 639-649, 2007.

Liu, P. L.-F., Cho, Y.-S., Yoon, S. B., and Seo, S. N.: Numerical simulations of the 1960 Chilean tsunami propagation and inundation at Hilo, Hawaii, in: Recent Developments in Tsunami Research, edited by: El-Sabh, M. I., Kluwer Academic Publishers, Dordrecht, the Netherlands, 99-115, 1994.

Martín García, J.: Theory and Practical Exercises of System Dynamics, ISBN 84-609-9804-5, Barcelona, 2006.

Meadows, D. H.: Thinking in Systems: A Primer, Chelsea Green Publishing Company, edited by: Wright, D., ISBN 978-1-60358055-7, 2008 
Mück, M.: Tsunami Evacuation Modelling, Development and application of a spatial information system supporting tsunami evacuation planning in South-West Bali, Diploma Degree Thesis, University of Regensburg, Bavaria, Germany, 2008.

Olabarrieta, M., Medina, R., González, M., and Otero, L.: C3: a finite volume - finite difference hybrid model for tsunami propagation and run-up, Comput. Geosci., 37, 1003-1014, 2011.

Okada, M.: Surface deformation due to shear and tensile faults in a half-space, B. Seismol. Soc. Am., 75, 1135-1154, 1985.

OECD (Organization for Economic Co-operation and Development)/EC-JRC (European Commission Joint Research Centre): Handbook on Constructing Composite Indicators, Methodology and Users Guide, OECD Publications, Paris, 2008.

Pickaver, A. H., Gilbert, C., and Breton, F.: An indicator set to measure the progress in the implementation of integrated coastal zone management in Europe, Ocean Coast. Manage., 47, 44962, 2004.

Rotmans, J. and Dowlatabadi, H.: Integrated assessment of climate change: evaluation of methods and strategies, in: Human Choices and Climate Change: a State of the Art Report, edited by: Rayner, S. and Malone, E. L., Batelle Pacific Northwest Laboratories, Washington, DC, 1998.

Sato, H., Murakami, H., Kozuki, Y., and Yamamoto, N.: Study on a simplified method of tsunami risk assessment, Nat. Hazards, 29, 325-340, doi:10.1023/A:1024732204299, 2003.

Sterman, J. D.: System dynamics: systems thinking and modeling for a complex world, Massachusetts Institute of Technology, Engineering Systems Division, Working Paper Series ESDWP-2003-01.13-ESD Internal Symposium, MIT Sloan School of Management, 2002.

Sterman, J. D.: Learning from Evidence in a Complex World, Am. J. Public Health, 96, 505-514, doi:10.2105/AJPH.2005.066043, 2006.

Strunz, G., Post, J., Zosseder, K., Wegscheider, S., Mück, M., Riedlinger, T., Mehl, H., Dech, S., Birkmann, J., Gebert, N., Harjono, H., Anwar, H. Z., Sumaryono, Khomarudin, R. M., and Muhari, A.: Tsunami risk assessment in Indonesia, Nat. Hazards Earth Syst. Sci., 11, 67-82, doi:10.5194/nhess-11-67-2011, 2011.

Sugimoto, T., Murakami, H., Kozuki, Y., and Nishikawa, K.: A human damage prediction method for tsunami disasters incorporating evacuation activities, Nat. Hazards, 29, 585-600, 2003.

Synolakis, C. E.: The runup of solitary waves, J. Fluid Mech., 185, 523-545, 1987.

Tinti, S., Tonini, R., Bressan, L., Armigliato, A., Gardi, A., Guillande, R., Valencia, N., and Scheer, S.: Handbook of Tsunami Hazard and Damage Scenarios, SCHEMA project (Scenarios for Hazard induced Emergencies Management), European Commission's Joint Research Centre, Institute for the Protection and Security of the Citizen, EU Publications Office, Luxembourg, ISBN 978-92-79-19062-9, doi:10.2788/21259, 2011.

Turner, B. L., Kasperson, R. E., Matson, P. A., McCarthy, J. J., Corell, R. W., Christensen, L., Eckley, N., Kasperson, J. X., Luers, A., Martello, M. L., Polsky, C., Pulsipher, A., and Schiller, A.: A framework for vulnerability analysis in sustainability science, P. Natl. Acad. Sci., 100, 8074-8079, 2003.

UN: Hyogo Framework for Action 2005-2015: Building the Resilience of Nations and Communities to Disasters, World Conference on Disaster Reduction, 18-22 January 2005, Kobe, Hyogo, available at: http://www.unisdr.org/2005/wcdr/intergover/ official-doc/L-docs/Hyogo-framework-for-action-english.pdf (last access: 18 March 2014), 2005.

UNDP: Risk Assessment and Management for Tsunami Hazard: Case Study of the Port City of Galle Sri Lanka, Published by United Nations Development Programme, Asia-Pacific Regional Centre (Thailand) in partnership with ICG/IOTWS Working Group on Risk Assessment under the UNESCO/IOC framework, 2011.

UNESCO: Hazard Awareness and Risk Mitigation in Integrated Coastal Management (ICAM), IOC Manual and Guides No. 50, ICAM Dossier No. 5, UNESCO, Paris, 2009a.

UNESCO: Tsunami risk assessment and mitigation for the Indian Ocean, Knowing your tsunami risk - and what to do about it, IOC Manuals and Guides No. 52, UNESCO, Paris, 2009b.

UN/ISDR (UN International Strategy for Disaster Reduction): Living with Risk: a Global Review of Disaster Reduction Initiatives, 2004 version, UN Publications, Geneva, 2004.

UN/ISDR (UN International Strategy for Disaster Reduction): Terminology on Disaster Risk Reduction, UN/ISDR, Geneva, Switzerland, 2009.

UNU-EHS (United Nations University - Institute for Environment and Human Security): Vulnerability Assessment within Cádiz test area (Western Iberian margin, Spain), Tsunami Risk ANd Strategies For the European Region (TRANSFER Project), available at: http://www.transferproject.eu (last access: 18 March 2014), 2009.

US IOTWS program (US Indian Ocean Tsunami Warning System Program): How resilient is your coastal community? A guide for evaluating coastal community resilience to tsunamis and other coastal hazards, US IOTWS Document No. 27, 144 pp., Bangkok, Thailand, 2007.

van Zuilekom, K. M., van Maarseveen, M. F. A. M., and van der Doef, M. R.: A decision support system for preventive evacuation of people, in: Geo-information for Disaster Management, edited by: Zlatanova, P., Van Oosterom, S., and Fendel, E. M., Springer, Berlin Heidelberg, 229-253, 2005.

Villagrán de León, J. C.: Rapid Assessment of Potential Impacts of a Tsunami: Lessons from the Port of Galle in Sri Lanka, No. 9, SOURCE Publication Series, United Nations University - Institute for Environment and Human Security (UNU-EHS), Bonn, 2008.

Vogel, C. and O'Brien, K.: Vulnerability and global environmental change: rhetoric and reality, AVISO No. 13, Global Environmental Change and Human Security Project, Carleton University, Ottawa, 2004.

Wang, X. M., and Liu, P. L.-F.: A numerical investigation of Boumerdes-Zemmouri (Algeria) earthquake and tsunami, CMES-Comp. Model. Eng., 10, 171-183, 2005.

Wegscheider, S., Post, J., Zosseder, K., Mück, M., Strunz, G., Riedlinger, T., Muhari, A., and Anwar, H. Z.: Generating tsunami risk knowledge at community level as a base for planning and implementation of risk reduction strategies, Nat. Hazards Earth Syst. Sci., 11, 249-258, doi:10.5194/nhess-11-249-2011, 2011.

Wijetunge, L. J.: A deterministic analysis of tsunami hazard and risk for the southwest coast of Sri Lanka, Cont. Shelf Res., 79, 23-35, doi:10.1016/j.csr.2013.09.009, 2014. 